\title{
Recent paleoseismic investigations in Northern and Western Thailand
}

\author{
Clark H. Fenton $\left({ }^{1}\right)$, Punya Charusiri $\left({ }^{2}\right)$ and Spencer H. Wood $\left({ }^{3}\right)$ \\ (1) URS Corporation, Oakland, CA, U.S.A. \\ $\left(^{2}\right)$ Department of Geology, Chulalongkorn University, Bangkok, Thailand \\ $\left({ }^{3}\right)$ Department of Geosciences, Boise State University, Boise, ID, U.S.A.
}

\begin{abstract}
Recent paleoseismic investigations have identified a number of active faults in Northern and Western Thailand. Northern Thailand is an intraplate basin and range province, comprised of north-south-trending Cenozoic intermontane grabens and half grabens, bounded by north- to northwest-striking normal to normal-oblique faults and northeast-striking left-lateral strike-slip faults. The basin-bounding normal faults are marked by steep, linear range fronts with triangular facets and wineglass canyons and have slip rates of 0.1 to $0.8 \mathrm{~mm} / \mathrm{yr}$. Based on limited data, the average vertical displacement-per-event is about 1.0 to $1.5 \mathrm{~m}$. These faults are characterized by recurrence intervals of thousands to tens of thousands of years and are capable of generating earthquakes up to moment magnitude $(\boldsymbol{M}) 7$, and larger. The northeast-striking strike-slip faults are marked by shutter ridges, and deflected drainages. Slip rates are $3 \mathrm{~mm} / \mathrm{yr}$ or less. Western Thailand is dissected by a number of northwest- and north-northwest-striking, right-lateral strike-slip faults related to the Sagaing Fault in Myanmar. Although showing much less activity than the faults in neighboring Myanmar, these faults display abundant evidence for late Quaternary movement, including shutter ridges, sag ponds, and laterally offset streams. The slip rate on these faults is estimated to be 0.5 to $2.0 \mathrm{~mm} / \mathrm{yr}$. These faults are considered capable of generating maximum earthquakes of up to $M 7^{1} / 2$.
\end{abstract}

Key words paleoseismicity - active faulting Thailand

\section{Introduction}

Due to a lack of large, damaging earthquakes during historical time, Thailand has not been considered to be a seismically active country. Although there are a number of accounts of historical earthquake damage (Nutalaya et al., 1985), the locations and sizes of most of these events are not well constrained. It is likely that some historical earthquake damage in Thailand may have been the result of large

Mailing address: Dr. Clark H. Fenton, URS Corporation, 500 12th Street, Suite 200, Oakland, CA 94607, U.S.A.; e-mail: Clark_Fenton@URSCorp.com earthquakes on distant faults such as the Sagaing Fault in Myanmar and faults in Southern China, which have been the locus of several magnitude (unspecified scale) $>6.0$ earthquakes during historical time (Le Dain et al., 1984). Recent seismicity in Thailand has been confined to low to moderate levels with no clear association with existing mapped faults (Bott et $a l ., 1997)$. In areas like Thailand, where there is no reliable, long-term earthquake record and an absence of historical fault surface ruptures, it is necessary to examine the geologic and geomorphic record, in order to quantify the activity on suspected active faults, and thereby determine their contribution to the seismic hazards of the region.

A fault is deemed active and is considered to be a potential source of future earthquakes if the fault: 1) displays geomorphic features indicative of recent fault activity; 2) there is evi- 
dence for displacement in young (Late Quaternary) deposits or surfaces; and/or 3) is associated with a moderate- to large-magnitude historical earthquakes or a pattern of microearthquakes suggestive of an active fault.

In this paper, we summarize the results of several recent investigations of active faults in Northern and Western Thailand. The evidence for active faulting, illustrated by examples from the Thoen, Pua, Mae Chan, and Three Pagodas faults, and the characteristics of these faults are discussed.

\section{Tectonic setting}

The contemporary tectonic framework of Southeast Asia is a consequence of the interaction between the Indo-Australian and Eurasian plates (fig. 1), and the more distant Philippine and West Pacific plates. The Eurasian plate, within which Thailand is situated, is surrounded by convergent margins, including the Andaman thrust and Sunda arc, to the west and south, respectively. Australia is moving northward (along a vector of $010^{\circ}$ to $020^{\circ}$ ), towards Southeast Asia, with a convergence rate of 65 to $70 \mathrm{~mm} / \mathrm{yr}$ (McCaffrey, 1996). In addition, Southeast Asia may also be moving towards Eurasia at a rate of $\sim 10 \mathrm{~mm} / \mathrm{yr}$. Deformation across these plate margins is diffuse. Partitioning of oblique convergence along the Andaman and Sumatra-Java margins gives rise to broad, complex zones of deformation (fig. 1) involving both subduction and transform faulting (Malod and Kemal, 1996), the most notable of the latter being the Sumatra Fault. Persistent deformation within the Eurasian plate is illustrated by the number of seismogenic faults in this region (Molnar and Deng, 1984).

Thailand occupies an intraplate setting within the Eurasian plate. The present tectonic stress regime in Thailand is one of transtension, with opening along north-south oriented basins and right-lateral and left-lateral slip on northwest- and northeast-striking faults, respectively (Polachan et al., 1991; Packham, 1993). This regime of transtensional faulting was initiated sometime between the Late Cretaceous and Early Tertiary (Polachan et al., 1991; McCabe et

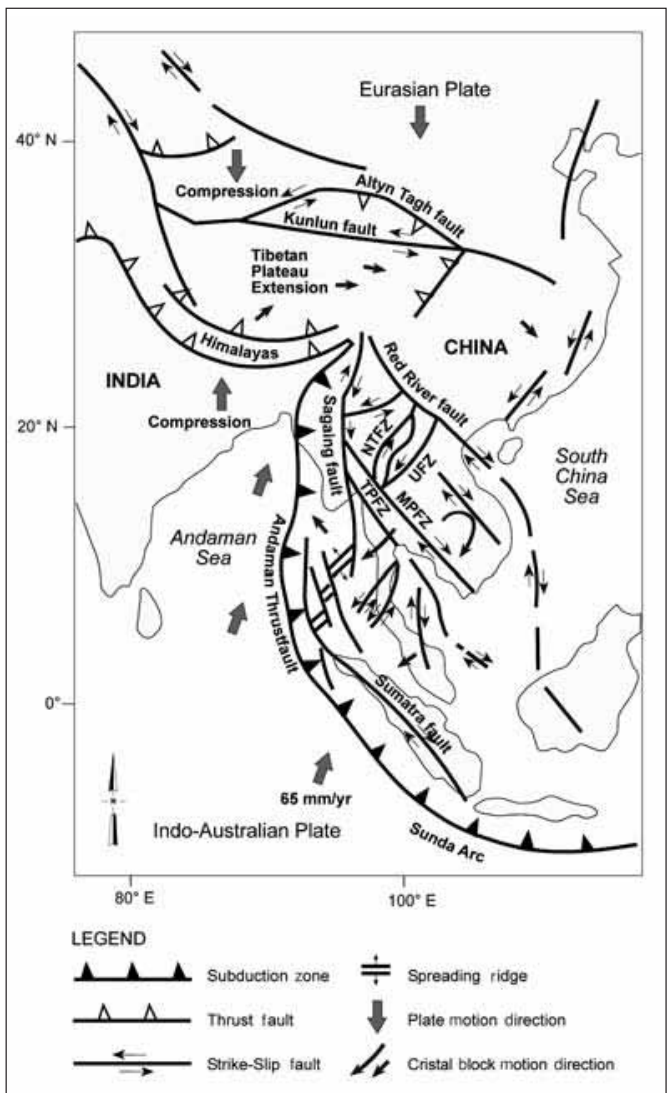

Fig. 1. Major tectonic elements in Southeast Asia and Southern China. Arrows show relative directions of motion of crustal blocks during the Late Cenozoic. MPFZ - Mae Ping Fault Zone; NTFZ - Northern Thailand Fault Zone; TPFZ - Three Pagodas Fault Zone; UFZ - Uttaradit Fault Zone. Modified from Polachan et al. (1991).

al., 1988). The Cenozoic tectonics of Thailand, and Southeast Asia as a whole, are a consequence of collision of India with Eurasia. Collision began about $50 \mathrm{Ma}$ (Middle Eocene) and has resulted in 2000 to $3000 \mathrm{~km}$ of shortening across the Himalayan orogen (Peltzer and Tapponnier, 1988). As India drove into the southern margin of Eurasia, Indochina was rotated clockwise about $25^{\circ}$ and extruded to the southeast by approximately $800 \mathrm{~km}$ along the Red River and Wang Chao-Three Pagodas 
fault zones during the first 20-30 million years of collision (Peltzer and Tapponnier, 1988). Extrusion migrated northwards onto the Altyn Tagh Fault as collision progressed. Rotation of Indochina continued, reversing the sense of motion of the Red River Fault from left-lateral to right-lateral (Allen et al., 1984; Peltzer and Tapponnier, 1988). Differential slip between the main strike-slip faults, from north to south, the Red River, Mae Ping, Three Pagodas, and Sumatra fault zones (fig. 1), created a transtensional regime that resulted in the opening of the Tertiary basins in Southeast Asia (Ducrocq et al., 1992).

The Tertiary basins of Thailand are grabens or half grabens, typically bounded by north to northwest-striking normal faults (Polachan et al., 1991; Lorenzetti et al., 1994). The location and geometry of the basins are controlled by the north-south structural grain in pre-Triassic rocks and pre-existing northwest-striking, strikeslip faults (O'Leary and Hill, 1989). Basin evolution throughout Thailand follows a roughly similar sequence of events. The main phase of strike-slip tectonism, resulting in rapid extension, with widespread fluvial sedimentation (Oligocene-Early Miocene), was followed by lacustrine sedimentation as basins became increasingly isolated (Early-Middle Miocene). Lacustrine sedimentation ended, and there was an influx of coarse terrigenous clastics suggesting a period of rapid, localized uplift (MiddleLate Miocene). Finally, following a brief period of basin inversion that resulted in a widely recognized Late Miocene unconformity, fluvial sedimentation, generally coarsening upward, resumed (Late Miocene-Recent) (Polachan et al., 1991; Remus et al., 1993; Alderson et al., 1994). The climax of extensional tectonism is marked by the eruption of Late Tertiary and Early to Middle Quaternary alkaline basalts (Hoke and Campbell, 1995). Paleomagnetic data, showing localized rotations during the Tertiary, indicates that the opening of these basins appears to have been fairly complex (McCabe et al., 1988, 1993; Richter et al., 1993).

With the exception of the lignite-bearing Mae Moh basin (e.g., Ratanasthien, 1986), few non-proprietary studies have been carried out to determine the detailed tectonic development of these basins. The total amount of extension across the region is unknown; Olinstad et al. (1989) estimate about $50 \mathrm{~km}$ of Cenozoic extension at the northern end of the Gulf of Thailand. In addition, the thickness of basinfill sediments is poorly constrained and the geometry of the basin-bounding faults are not well known. Many of the basins, however, are bounded by linear escarpments that display a number of geomorphic features suggesting that they may still be active structures (Siribhakdi, 1986).

\section{Seismotectonic provinces}

We have modified the seismotectonic zones of Nutalaya et al. (1985), incorporating geologic, heat flow, and fault activity data, to better represent the seismotectonic character of Thailand (fig. 2). Most of Northern Thailand falls within what, on account of its tectonic similarities with the Basin and Range Province of the Western United States, Fenton et al. (1997) have called the Northern Basin and Range Province. This is a region of extended crust, forming basin and range topography (MacDonald et al., 1993). Heat flow is presently moderate to locally high and probably has been since the initiation of rifting in the early Tertiary (Raksaskulwong and Thienprasert, 1991). To the west the Northern Basin and Range is bounded by the Western Highlands, a region of lower heat flow, comprising uplifted and complexly folded and faulted metamorphic rocks. This province is traversed by a number of northwest- to north-northwest-striking rightlateral strike-slip faults, including the Three Pagodas and Mae Ping faults, which splay from the Sagaing Fault in Eastern Myanmar (fig. 1). To the east of the Northern Basin and Range is the Loei or Eastern Fold Belt, a transitional zone between the extended crust of the Northern Basin and Range and the Korat Plateau, an uplifted plateau region with subdued topography, low heat flow, and apparent tectonic quiescence. To the south the Northern Basin and Range transitions into the Central Plain (also known as the Chao Praya Basin) which in turn transitions into the Gulf of Thailand. Each of these provinces is a 


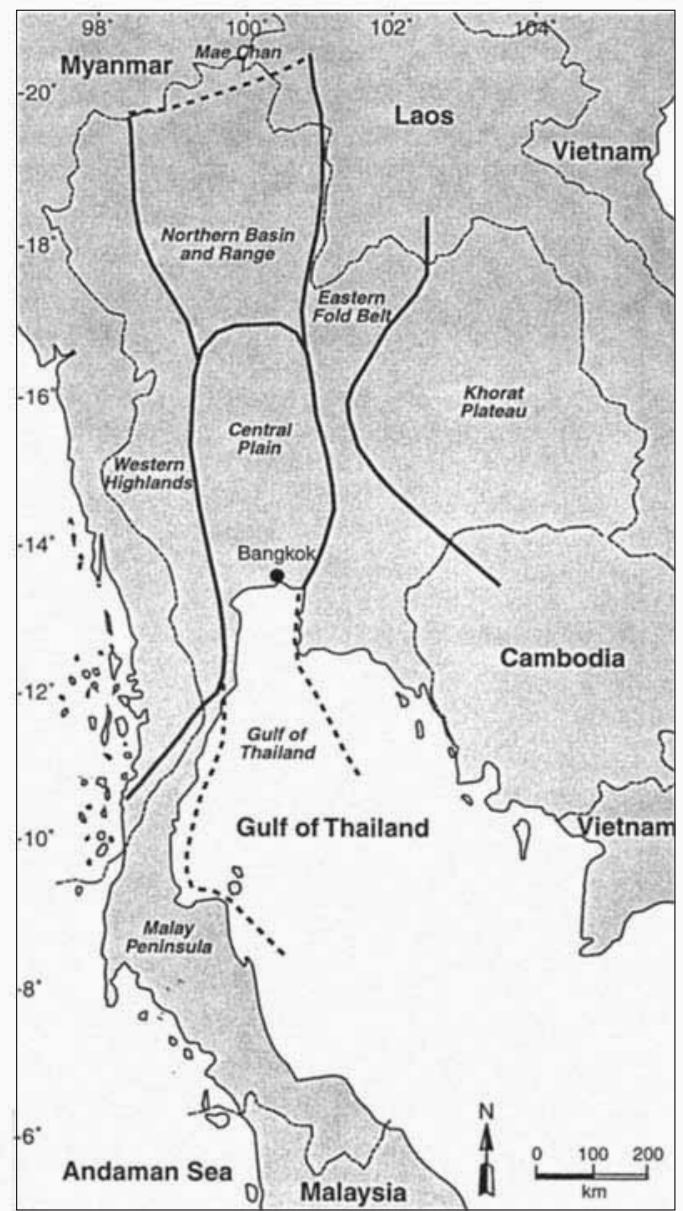

Fig. 2. Seismotectonic provinces in Thailand (after Woodward-Clyde Federal Services, 1996).

region of extended crust, distinguished by an increasing amount of extension and subsidence towards the south. Whereas the Northern Basin and Range comprises a number of distinct basins, separated by intervening ranges, the Central Plain has extended to the point where it has created a single, broad, alluvium-filled topographic basin. North of the Northern Basin and Range is a region dominated by left-lateral strike-slip deformation. This is called the Mae Chan Province after the active strike-slip fault that appears to mark the southern boundary of this deformation.

\section{Historical seismicity}

Contemporary seismicity in the Northern Basin and Range province is diffusely distributed, of low to moderate levels, does not appear to be associated with currently mapped faults (fig. 3), and is probably confined to the upper 10 to $20 \mathrm{~km}$ of the crust (Bott et al., 1997). Although the historical earthquake record extends back to at least 1300 A.D. (year 1843 B.E., Thai calendar), the largest known earthquake in Thailand has probably not exceeded Richter magnitude $\left(M_{L}\right) 6 \% \frac{1}{2}$. Associating seismicity with specific geologic structures, particularly mapped faults, is extremely difficult in Northern Thailand because of the large location uncertainties of individual earthquakes (Bott et al., 1997). In fact, in common with the Basin and Range Province in the Western United States, much of the widely distributed seismicity in Northern Thailand is probably associated with faults that have no clear surface expression (Bott et al., 1997). In the Basin and Range Province, these so-called background earthquakes can be as large as $\boldsymbol{M} 6$ to $6^{1 / 2}$ (dePolo, 1994).

\section{Previous fault studies}

With the exception of limited ground cracking accompanying the $1983 M_{L} 5.9$ reservoirinduced earthquake at Srinagarind reservoir (Klaipongpan et al., 1991), there are no reports of historical surface faulting events in Thailand. Nutalaya (1994) and Hinthong $(1995,1997)$ initially compiled data on active faults in Thailand, identifying 22 active, potentially active, or suspected active faults, based primarily on geomorphic expression and thermoluminescence ages obtained from fault gouges. Subsequent investigations have added to the inventory of active and suspected active faults in Thailand (fig. 4). Thiramongkol (1986) presented evidence for Holocene movement on the Bang Pakong Fault on the eastern margin of the Central Plain. Le Dain et al. (1984) suggested that the northweststriking Papun (Moei or Mae Ping) Fault might also be active, based on recent seismicity recorded in the Myanmar-Thailand border region 


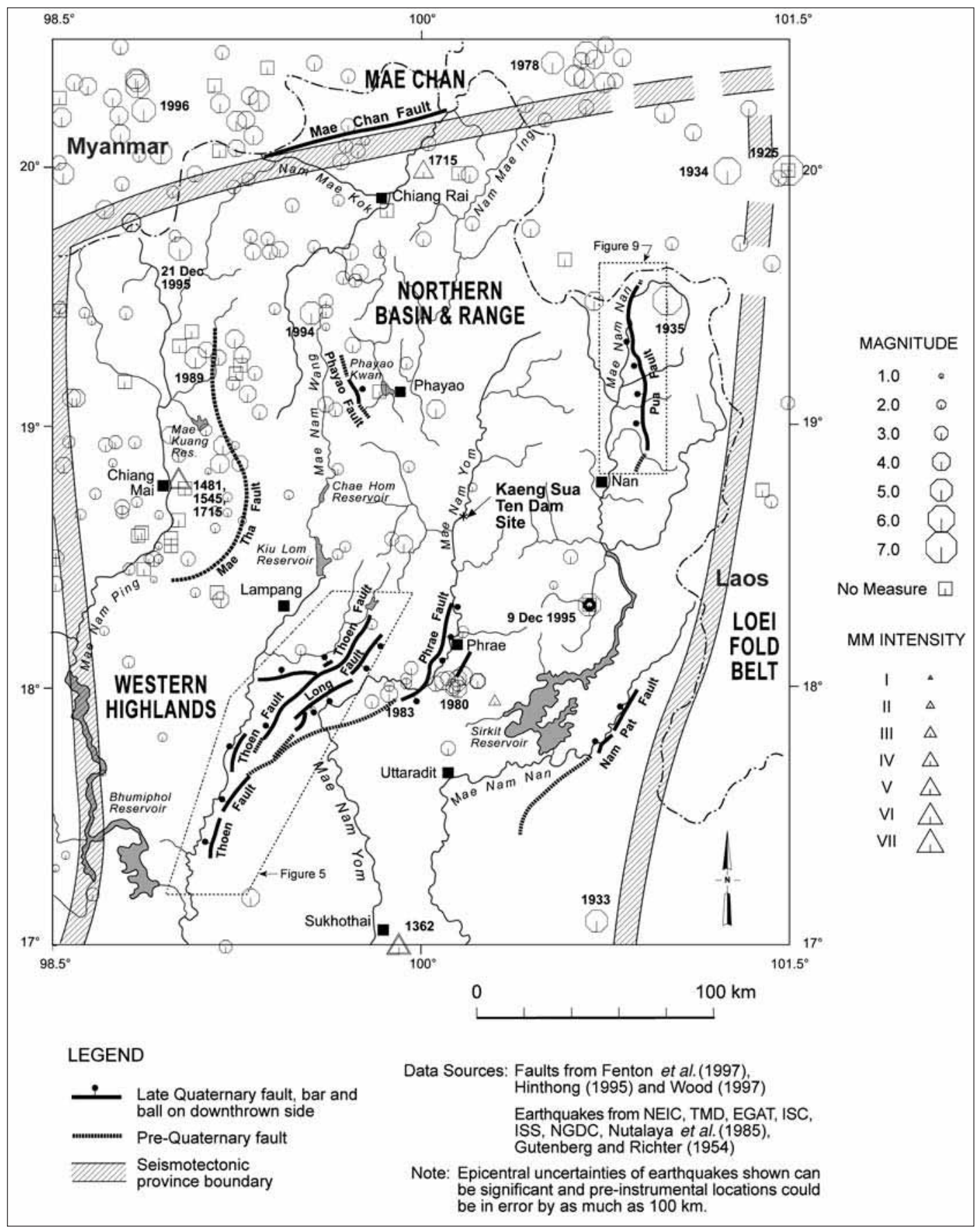

Fig. 3. Late Cenozoic faults and historical seismicity (1362 to 1996) of the Northern Basin and Range seismotectonic province. Figure modified from Bott et al. (1997). 


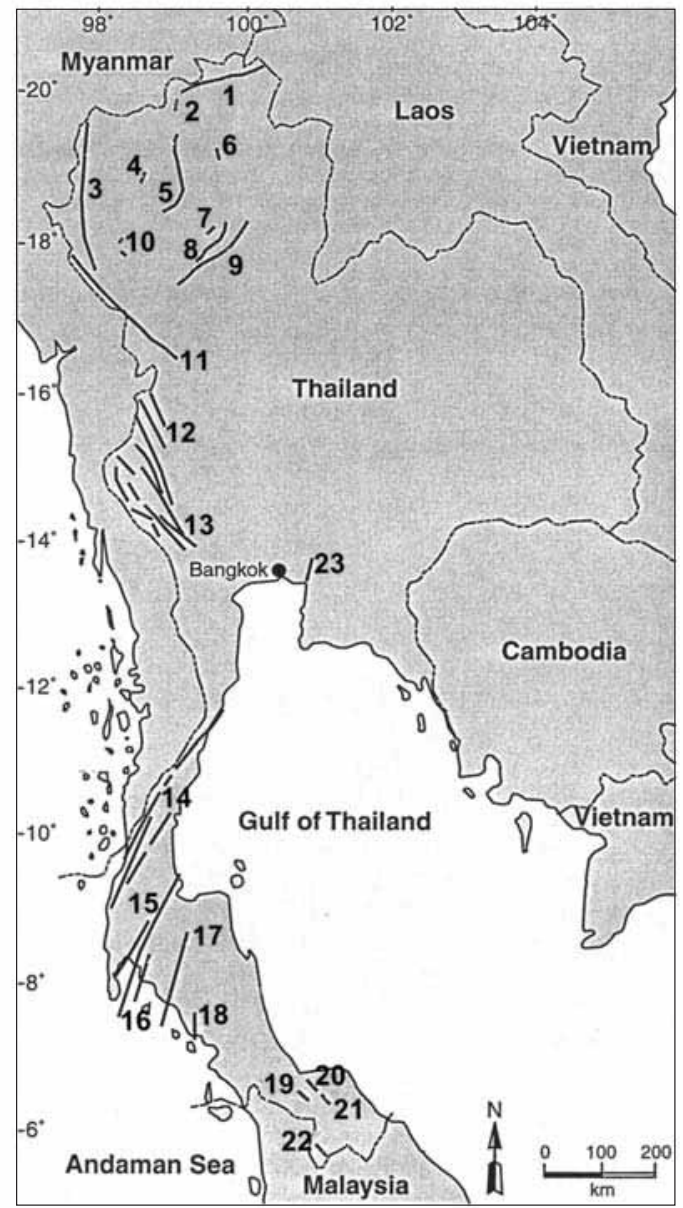

$\begin{array}{llll}1 & \text { Mae Chan Fault } & 13 & \text { Three PagodasFault Zone } \\ 2 & \text { Fang Fault } & 14 \text { RanongFault Zone } \\ 3 & \text { Mae SaraingFault Zone } & 15 \text { Klong MauriFault Zone } \\ 4 & \text { Mae Rim Fault } & 16 \text { Ao LukFault Zone } \\ 5 & \text { Mae ThaFault Zone } & 17 \text { Khlong Thom Fault Zone } \\ 6 & \text { Wang Nua Fault } & 18 \text { Kantang Fault } \\ 7 & \text { Mae Chang Fault } & 19 \text { Saba Yoi Fault } \\ 8 & \text { ThoenFault Zone } & 20 \text { Khok Pho Fault } \\ 9 & \text { PhraeFault Zone } & 21 \text { Yala Fault } \\ 10 \text { Hot Fault } & 22 \text { BetongFault } \\ 11 \text { MoeiFault Zone } & 23 \text { Bang PakongFault } \\ 12 \text { Si SawatFault Zone } & \end{array}$

Fig. 4. Active and suspected active faults in Thailand. Modified from Hinthong (1995).

(fig. 1). Earthquake focal mechanisms suggest that this fault is a right-lateral, strike-slip fault (Le Dain et al., 1984). Woodward-Clyde Federal Services (1996) carried out extensive fault investigations in Northern Thailand that showed recent activity on the Mae Chan, Pua, Phrae, Phrae Basin, Thoen, Nam Pat, Long, and Phayao faults (fig. 3). Rhodes et al. (1996) reported young faulting within Cenozoic sediments along the margin of the Chiang Mai basin, west of the city of Chiang Mai. Perez et al. (1999) inferred recent movement on the Mae Kuang Fault, northeast of Chiang Mai, from the offset of three tributaries of the Mae Kuang River. Wood (1995, 2001) provided strong geomorphic evidence for Late Quaternary left-lateral displacement along the Mae Chan Fault. Recent trenching investigations have confirmed Late Quaternary faulting on the Mae Chan Fault (Rymer et al., 1997). Woodward-Clyde Federal Services (1998) highlighted evidence for recent movement on the Three Pagodas Fault in Western Thailand and also on the Tavoy, Tenasserin, and Kungyaungale faults in neighboring peninsular Myanmar.

\section{Approach of recent investigations}

The identification of active faults in Thailand has been hampered by: 1) the comparative lack of fault studies; 2) extensive weathering of bedrock and extremely active erosion acting together to prevent the preservation of all but the most resistant geomorphic features; 3) large areas of thick forest vegetation, and 4) the probable low slip rates of the intraplate faults in Thailand. Combined, these factors result in a lack of recognizable, long-lived surfacefaulting geomorphic features (Fenton et al., 1999). Despite these shortcomings, paleoseismic investigations in Thailand have been successful and indicate that Late Quaternary deformation is ongoing and that these active faults pose a significant seismic hazard (e.g., Wong et al., 1997).

Lacking a well-defined Late Quaternary framework for Northern Thailand, recent studies (e.g., Fenton et al., 1997) concentrated on the geomorphic expression of faulting, and the comparison with the features observed along other active faults in similar tectonic settings worldwide. These features included fault scarps, faceted spurs, and offset terraces and drainages. These geomorphic data were supplemented by 
paleoseismic data obtained from limited trenching and fault zone exposures (Woodward-Clyde Federal Services, 1996; Fenton et al., 1999).

Ideally, investigations of active faults progress from a regional, through a local, to a sitespecific scale. In areas where there is some data on the regional neotectonic setting, the emphasis of such studies is on the local and site-specific scale. In Thailand, where damaging earthquakes are infrequent and possibly there are no surface-faulting events in historical time, the regional, as well as local seismotectonic setting is not well understood. Therefore, investigations have to start at a regional level, and progress through a series of logical steps towards detailed site-specific studies.

Initial studies involved remote sensing interpretation, starting at small scales with satellite imagery, progressing to detailed stereoscopic aerial photographs to locate zones of active deformation (Wood, 1995, 2001; Fenton et al., 1997). Once these zones were identified, detailed mapping of Quaternary landforms and deposits along a zone of deformation was carried out. The Quaternary stratigraphic framework was then established and landform styles identified. Based on the estimated ages of these features and/or deposits, they were used to measure the amount and the rates of displacement across faults (Wood, 1995, 2001). Geomorphic mapping aided in evaluating the location of active faults and the nature of the faulting, identifying the number of paleo-events, and the approximate size and timing of these events (Fenton et al., 1999).

Finally, when there was sufficient knowledge of the local Quaternary stratigraphy and geomorphology with which to evaluate the results of detailed trench logging, we excavated and logged a number natural fault zone exposures. A number of the faults investigated, even after detailed geomorphic studies, were not considered suitable for trenching studies because of the lack of preservation of young deposits along the fault zones. These faults, although having very prominent geomorphic expressions, usually as topographic escarpments with faceted spurs with oversteepened bases (Hamblin, 1976), are rarely expressed in young geologic materials.
These studies have allowed us to estimate a number of fault parameters including: the total amount of offset across fault zones; slip-perevent; fault slip rates; recurrence intervals; fault segmentation, and bracket the age of faulting events. The geomorphic evidence for Late Quaternary faulting in Thailand is discussed in the following sections, illustrated by examples from the Thoen, Pua, Mae Chan, and Three Pagodas fault zones.

\section{Thoen Fault}

The $120 \mathrm{~km}$ long Thoen Fault Zone (fig. 3) is a series of north- to northeast-striking faults that traverse the region between the Phrae Basin to the east and the Lampang, Mae Moh, and Thoen basins to the west (Piyasin, 1974; Charoenprawat et al., 1994). Two faults within this

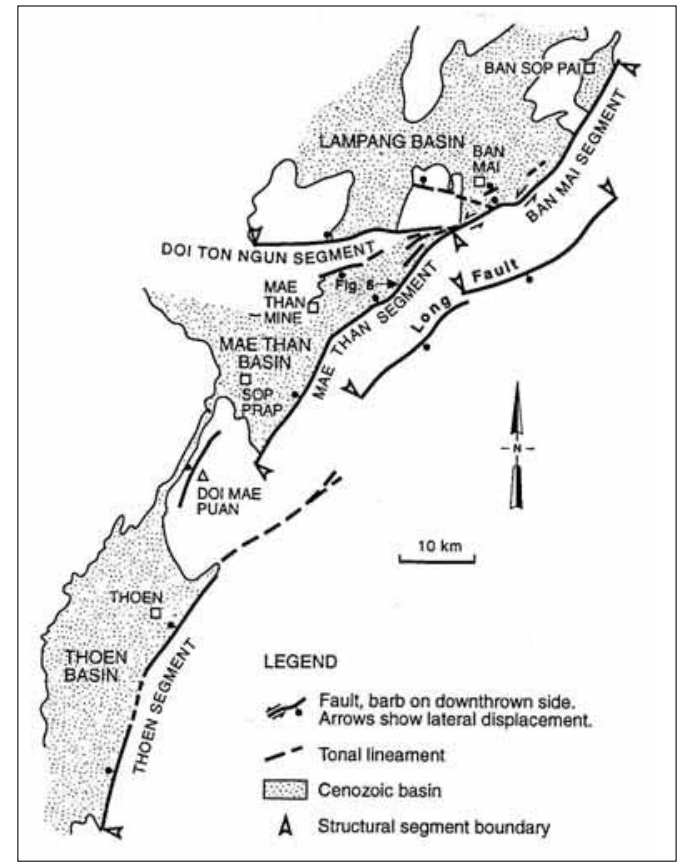

Fig. 5. Simplified map of the Thoen Fault System showing fault segments and localities mentioned in the text. 
system display a number of structural, stratigraphic, and geomorphic features indicating recent movement. They are the fault bounding the eastern margins of the Mae Moh, Lampang, and Thoen basins, herein called the Thoen Fault, and the fault bounding the western side of the Long Valley, the Long Fault (fig. 5).

On aerial photographs and Landsat TM satellite imagery, the Thoen Fault is a well-defined, sharp lineament. The predominantly vertical offset across the fault is highlighted by the contrast between the deep incision by streams in the uplifting footwall compared to the lack of incision on the same streams in the subsiding footwall, i.e. denudation and aggradation in the footwall and hangingwall, respectively, of an active fault. The Thoen Fault can be divided into four segments, based on geomorphic expression, structural style, and sense of offset. From north to south these are the Ban Mai, Doi Ton Ngun, Mae Tan, and Thoen segments (fig. 5).

Over much of its length, the Thoen Fault forms a northwest-facing bedrock escarpment that varies in height from 400 to $600 \mathrm{~m}$. The escarpment comprises a series of faceted spurs interrupted by several benches or erosional pediment remnants (fig. 6). Hamblin (1976) has shown that such features were the result of episodic fault movement; the facets forming during periods of fault movement and the benches during periods of tectonic stability, erosion and fault scarp retreat (fig. 7). Studies of faults in the Mae Moh Basin, immediately to the west of the Thoen Fault, have shown that extension began sometime in the Early Oligocene (Vella, 1983; Ratanasthien, 1986). These faults show a complex history of movement throughout the Tertiary, however, they now appear to be rela-

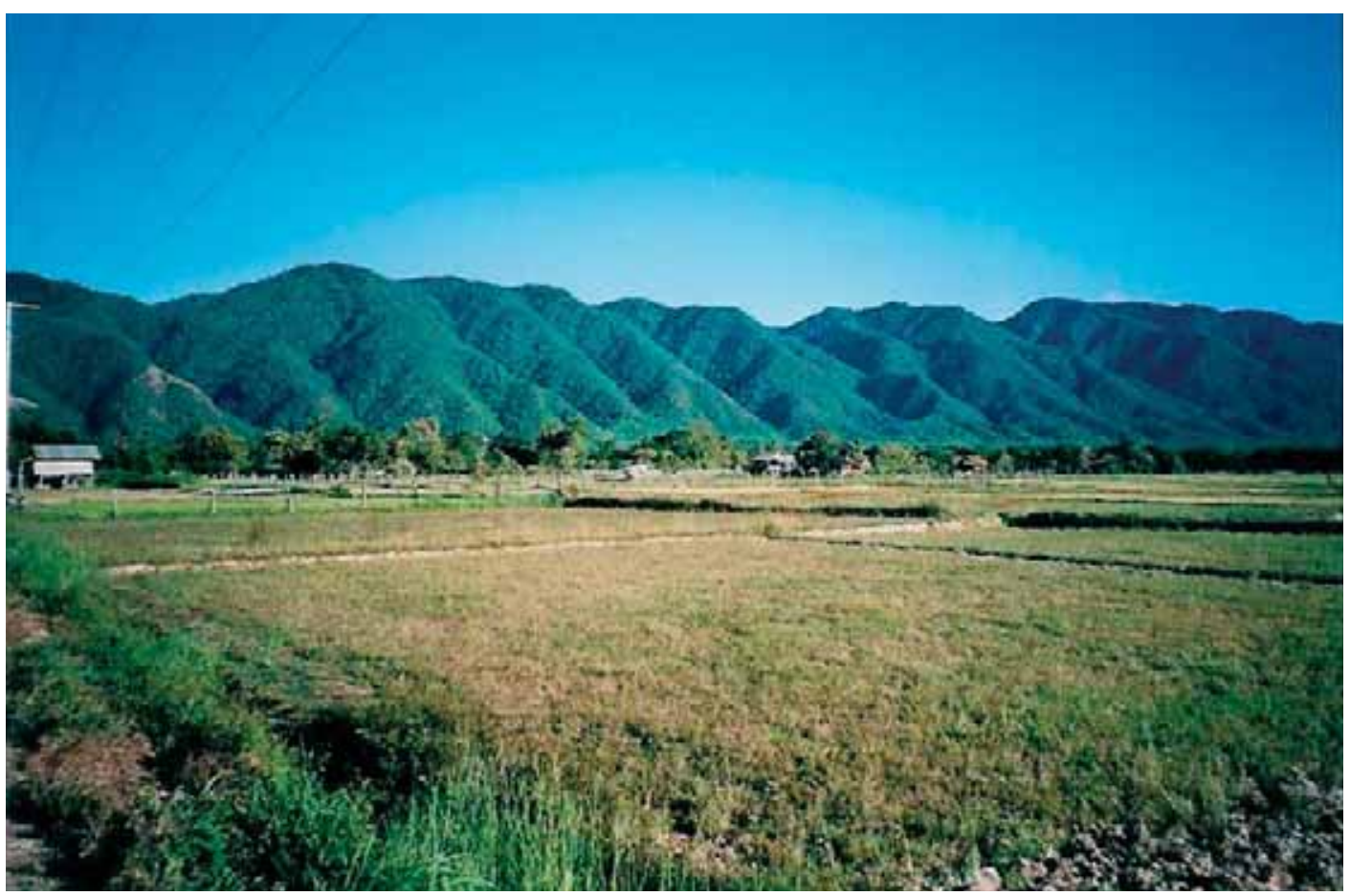

Fig. 6. Triangular faceted spurs along the Thoen Fault escarpment east of Ban San Pa Pao. Note the oversteepened base and the development of several erosional benches along the escarpment. 


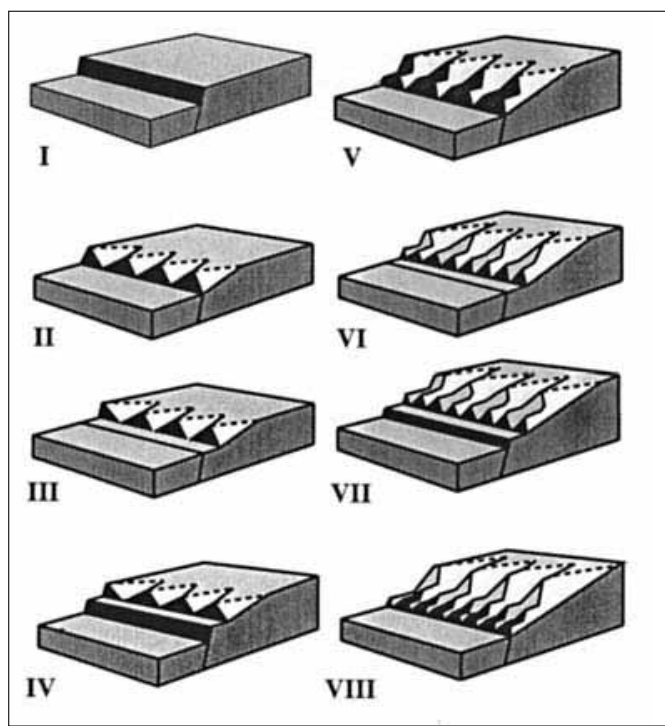

Fig. 7. Development of faceted spurs produced by episodic vertical tectonic movement. I - undissected fault scarp. II - development of faceted spurs by streams cutting across the fault scarp. III - period of tectonic quiescence with slope retreat, and development of a narrow pediment. IV - renewed fault movement. V - dissection of the new fault scarp by major streams and streams developed on the faces of the faceted spurs developed at stage II. VI - a new period of tectonic quiescence, with the development of another narrow pediment within the footwall block at the base of the range front. VII - renewed fault movement. VIII - dissection of the fault scarp produced at stage VII resulting in a line of small faceted spurs at the base of the range front. Remnants of narrow pediments (benches) are preserved at the apices of each set of faceted spurs. Progressive slope retreat is accompanied by a decrease in the slope angle of the faceted spurs. Modified from Hamblin (1976).

tively inactive (Ratanasthien, 1986). The most recent movement, therefore, appears to have been confined to the margins of the basin along the main Thoen Fault.

Along the Ban Mai Fault Segment, the lowest faceted spurs are about 250 to $350 \mathrm{~m}$ high. These facets themselves are not planar, but comprise at least three beveled planes that steepen towards the base of the escarpment.
Progressive steepening towards the base of a fault scarp or escarpment shows repeated fault movement, the steeper bevels representing more recent (less eroded fault scarps) faulting episodes (McCalpin, 1996).

Several streams crossing the Ban Mai Segment exhibit wine-glass canyon profiles. This results from renewed uplift or an increased rate of uplift of the footwall in a normal fault system (fig. 8). In order to equilibrate their profiles across a fault-produced knickpoint, streams may have to cut down rapidly when fault movement either resumes after a period of tectonic quiescence or when the rate of movement increases. The result of this rapid down-cutting is the formation of a narrow slot canyon or stem of the wine-glass. The presence of wineglass canyons in addition to the marked steepening of the faceted spurs at the base of the escarpment, indicate that, at least along the Ban Mai Segment, the Thoen Fault is undergoing renewed or increasing vertical displacement. Vertical offset has also resulted in a sudden widening of drainage valleys as they cross from the footwall into the hangingwall. These valley floors and the adjacent ridge crests also show left-lateral offset across the fault. Valley walls are offset in a leftlateral sense by approximately 200 to $400 \mathrm{~m}$.

At Ban Mai, the Thoen Fault crosses the active floodplain of the Mae Mai River (fig. 5) and vertically offsets an alluvial terrace surface, down-to-the-northwest, by approximately $6 \mathrm{~m}$. The absolute age of this terrace surface is unknown; however, from the preservation of the terrace and the relatively immature soil development on the terrace surface (a $B_{w}$ horizon with only limited rubification), we consider this surface to be Holocene in age. Assuming approximately $6 \mathrm{~m}$ of vertical offset during the Holocene, this gives a vertical displacement rate of about $0.6 \mathrm{~mm} / \mathrm{yr}$ for the Ban Mai Segment.

A road cut about $1 \mathrm{~km}$ west of the main escarpment at Ban Mai (fig. 5) exposes a normal fault offsetting, down-to-the-west, a sequence of alluvial gravels and lacustrine clays. The fault dips about $80^{\circ} \mathrm{W}$ and strikes $\mathrm{N} 48^{\circ} \mathrm{E}$. Total vertical displacement exposed in the cut is 1.3 to $1.6 \mathrm{~m}$. The number of events and the amount of slip-per-event is unknown, as the top 


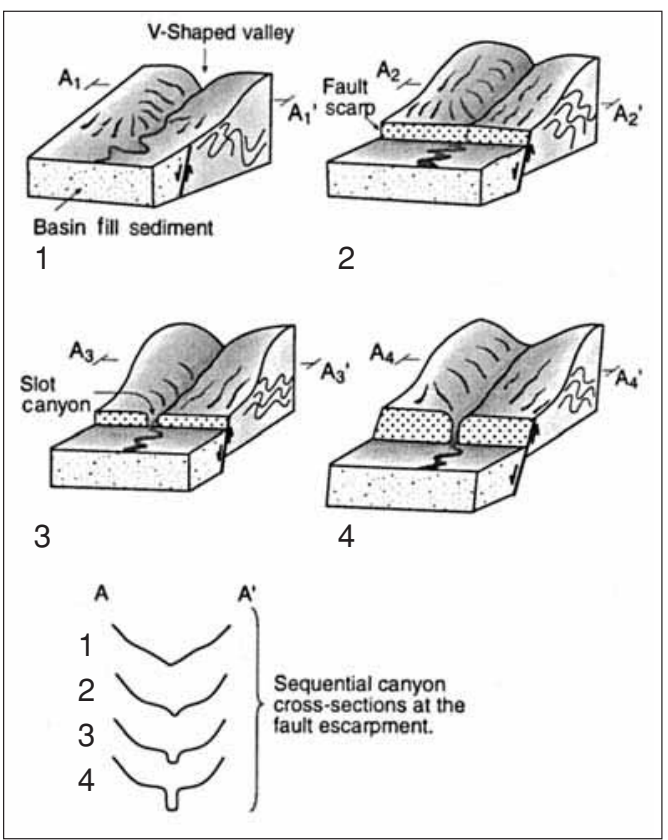

Fig. 8. Formation of a wineglass canyon. From Woodward-Clyde Federal Services (1996). 1 - Tributary drainage crosses normal faulted basin margin at grade. 2 - Normal faulting event. Tributary drainage offset vertically. 3 - Drainage erodes down to new base level. 4 - Repeated fault movement. Scarp height increases, as does depth of slot canyon if rate of faulting is greater than erosion.

of the section has been eroded. Young, unfaulted gravel (probably Holocene in age) has been deposited across this eroded surface and is not offset by the fault. Faulting is assumed to be Late Quaternary in age on account of the poorly developed soils both in the unfaulted unit crossing the fault and also within the upper offset units. The relationship between this fault and the main Thoen Fault is unknown. Its location and geometry suggest that it must be a synthetic fault, i.e. it has the same dip and sense of movement as the main fault. A lack of geomorphic expression and the pre-Holocene offset, however, indicates that it is less active than the main basin-bounding fault.

With the exception of these two localities, no other faulting is found in young deposits along the Ban Mai Segment. The lack of observed recent faulting over much of the northern segment of the Thoen Fault is due to the relative absence of young deposits along the fault trace. Where present, mainly along modern drainage courses, these deposits are very young, most likely less than a few thousand years old (Woodward-Clyde Federal Services, 1996). In addition, rice farming has extensively modified these deposits. The high rates of erosion in Northern Thailand result in very little aggradation along active drainages in upland regions (Kiernan, 1991).

The $25 \mathrm{~km}$ long east-west-striking Doi Ton Ngun Fault Segment forms a $300 \mathrm{~m}$ high range front with well-developed triangular facets and wine-glass canyons (fig. 5). The facets have three well-developed bevels: the lowest is about 3 to $5 \mathrm{~m}$ high and dips $45^{\circ}$; the intermediate bevel is about $25^{\circ}$ to $30^{\circ}$ and about $100 \mathrm{~m}$ high; and the upper bevel is $15^{\circ}$ to $20^{\circ}$ and extends to the crest of the range. The lowest bevel corresponds to a prominent scarp observed on aerial photographs (Fenton et al., 1997). All streams crossing this fault splay show marked incision on the footwall, indicating vertical offset. No evidence for lateral offset is observed. With the exception of some minor faulting and tilting of alluvial gravels in a borrow pit at the eastern end of this segment, no faulting was observed in young deposits. Displacement appears to die out rapidly westwards. The Late Pliocene-Early Pleistocene Kho Kha basalts (Sutthirat et al., 1995) are offset by less than $1 \mathrm{~m}$, and the fault does not appear to cut through the entire sequence of basalt flows.

The Mae Than Segment of the Thoen Fault is comprised of a number of splays that strike northeast to east-northeast (fig. 5). These splays bound the Tertiary Mae Than Basin. The main fault, bounding the southeastern side of the basin, forms a $600 \mathrm{~m}$ high, northwest-facing escarpment characterized by well-developed triangular facets and wineglass canyons (fig. 6). A well-developed bench is observed at the apices of $280 \mathrm{~m}$ high triangular facets. These facets show progressive steepening towards their bases. Drainages crossing the fault show extensive footwall incision, but no evidence for lateral displacement. These drainages appear to 
have been ponded within the graben as shown by the sudden widening of their respective flood plains as they flow in and then narrow again as they flow out of the graben. No fault exposures were found in young alluvial deposits. Exposures in the Mae Than lignite mine (fig. 5 ) show that none of the faults on the northwest side of the graben have been active during Late Quaternary time.

South of Mae Than, at the base of the main fault escarpment, at least two, possibly three, Late Cenozoic, down-to-the-northwest faulting events are preserved as stacked colluvial wedges in a sequence of alluvial fan gravels exposed in a stream cut-bank. The age of these deposits is unknown; however, the degree of reddening and cementation of these gravels almost certainly precludes them from being Holocene. Clasts size, mainly cobbles and boulders, is also incompatible with the size of the present drainages issuing from the footwall block. We conclude, therefore, that these gravels are PlioPleistocene in age. The thickness of individual colluvial wedges, approximately 1.0 to $1.5 \mathrm{~m}$, indicates faulting events with comparable amount throw. Assuming a similar $0.6 \mathrm{~mm} / \mathrm{yr}$ vertical displacement rate, as calculated for the Ban Mai segment, this would suggest that the return period for the Mae Than segment is about 2500 years.

To the south of Sop Prap (fig. 5), some indication of the total vertical offset across the Mae Than Segment is shown by the displacement of a pre-Tertiary peneplain surface. Assuming the 600 to $800 \mathrm{~m}$ vertical displacement of this surface has occurred since the initiation of normal faulting in Northern Thailand, approximately $33 \mathrm{Ma}$ (Charusiri, 1989), this gives a long-term vertical displacement rate of $0.02 \mathrm{~mm} / \mathrm{yr}$. This value, however, averages older, slower rates of activity with the higher, more recent rate that has produced the faceted spurs and wine-glass canyons. Therefore, this slip rate must be considered a minimum value.

South of Sop Prap, the Thoen Fault steps right and follows the base of the Doi Mae Puan range front (fig. 5). This segment of the fault, although marked by a linear range front, is much more subdued than the other fault segments, suggesting that it has a lower slip rate.

\section{Pua Fault}

The Pua Fault is a $68 \mathrm{~km}$ long, north-striking, west-dipping normal fault bounding the eastern margin of the Tertiary Pua Basin (figs. 3 and 9). On aerial photographs and Landsat TM satellite imagery, the fault forms a very prominent west-facing escarpment that gradually decreases in height and definition from north to south. The fault has three distinct segments: the linear northern Thung Chang Segment; the concave-west central Pua Segment; and the linear southern Santi Suk Segment (fig. 9). The most prominent tectonic geomorphology is observed along the northern and central segments where the fault is marked by a steep, west-facing escarpment with triangular facets and wineglass canyons. The base of the escarpment is progressively oversteepened. Drainages crossing the escarpment are deeply incised in the footwall and have little or no incision in the hangingwall. Terrace fragments are preserved along several drainages within the footwall block. The geomorphic expression of the southern segment of the fault is less pronounced. The fault is still marked by a prominent oversteepening at the base of the escarpment. The escarpment gradually decreases in height toward the south until the fault no longer has any topographic expression. The fault may continue to the south for another $5 \mathrm{~km}$ as a prominent bedrock fracture striking north-northeast - southsouthwest.

The Thung Chang Segment (fig. 9) of the fault is marked by a linear escarpment, comprising triangular faceted spurs and wine-glass canyons. The facets show a marked steepening towards the base of the escarpment and have at least two bevels at higher elevations. The steepened section at the base of the escarpment is up to $10 \mathrm{~m}$ high. Where alluvial fans are better developed, this steepening is manifest as a warping, down-to-the-west, of the fan surface creating low-angle (about 10 to $15^{\circ}$ ) scarps (fig. 10). A number of drainages along this segment of the fault have been beheaded, suggesting that there is also a lateral component of slip. The offset of these drainages is ambiguous, thus, the sense of lateral slip is not clear. The offsets of terrace margins along one drainage appear to be 


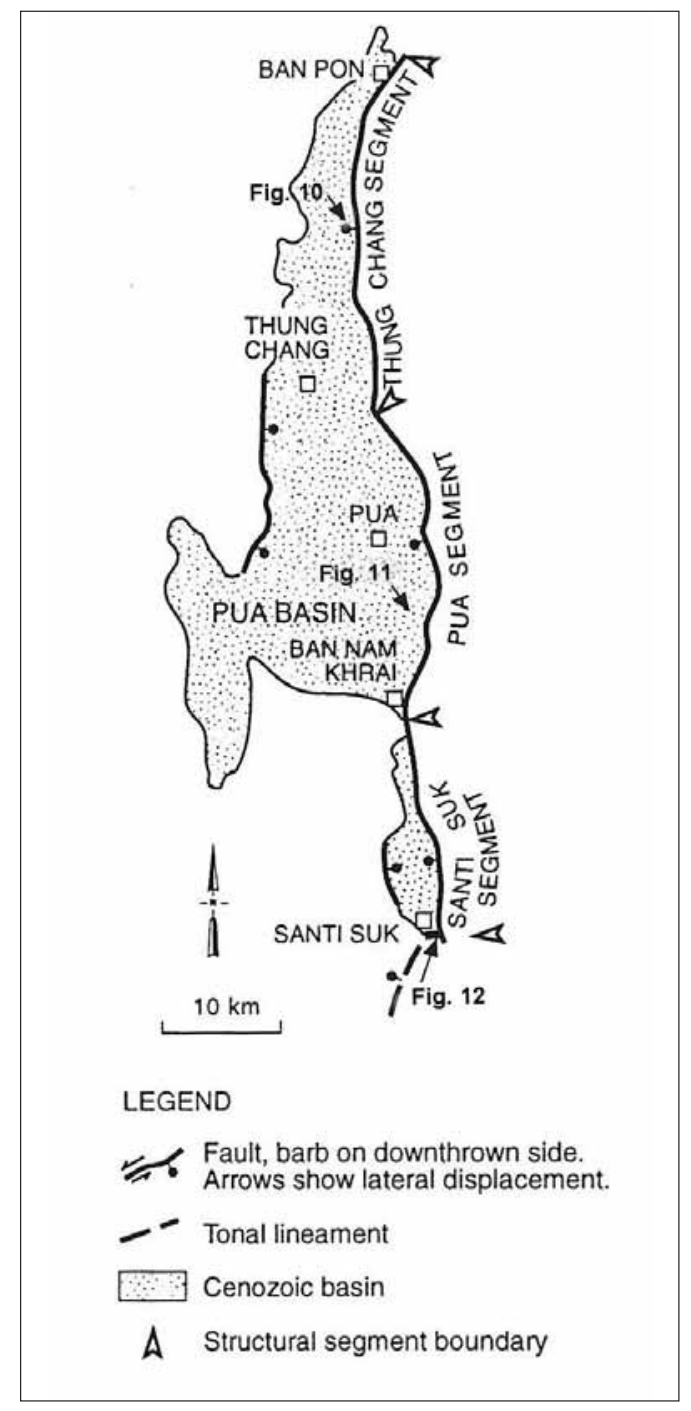

Fig. 9. Simplified map of the Pua Fault System showing fault segments and localities mentioned in the text.

right-lateral. The amount of lateral offset, however, is relatively small $(<10 \mathrm{~m})$ compared with the vertical offset. The southern end of the Thung Chang Segment is marked by a prominent fault bend where the strike of the range front changes from north to northwest.
The $24 \mathrm{~km}$ long Pua Segment is concave to the west (fig. 9). The central part of this fault segment displays the highest and steepest triangular facets found along the Pua Fault, and also displays some of the best-developed wine-glass canyons in Northern Thailand (fig. 11). This increased definition of the fault escarpment is coincident with a widening of the Pua Basin (fig. 9). The base of the escarpment is oversteepened and small terrace fragments appear to have been stranded along tributary drainages as a result of footwall uplift. Assuming that these uplifted terrace fragments were formed at similar elevations to the alluvial fan surfaces within the basin (hangingwall), then the terrace fragments along the Khun and Khwang rivers have been offset vertically by at least $50 \mathrm{~m}$. The age of these terrace surfaces, however, is unknown and therefore they cannot be used to determine the fault slip rate. No evidence for lateral movement has been found along this segment of the fault. At Ban Nam Khrai, the fault again changes orientation to a more north-northwest strike (fig. 9) and the height of the escarpment decreases markedly. This bend in the fault corresponds with an intrabasin high and it also marks the boundary between the Pua and Santi Suk segments of the fault.

The Santi Suk Segment (fig. 9) comprises the most subdued topography along the Pua Fault, although the fault escarpment displays the same geomorphic features indicative of active faulting found along the other two fault segments. This segment is marked by an escarpment that decreases in height from about 200 to $100 \mathrm{~m}$ over a distance of about $12 \mathrm{~km}$. At its northern end, this escarpment has well defined triangular facets with oversteepened bases. The oversteepened bevel at the base of the escarpment is about $6 \mathrm{~m}$ high. The low faceted spurs at the southern end of the Santi Suk Segment show at least three bevels, the lowest and steepest (approximately 22 $2^{\circ}$ ) of which is about $6 \mathrm{~m}$ high. This bevel is uniformly well developed along the entire Santi Suk Segment. The age of alluvial surfaces offset by this bevel is unknown; however, the lack of incision and preservation of these surfaces suggests that they are likely to be Holocene in age (Fenton et al., 1997). Assuming that the bevel at 


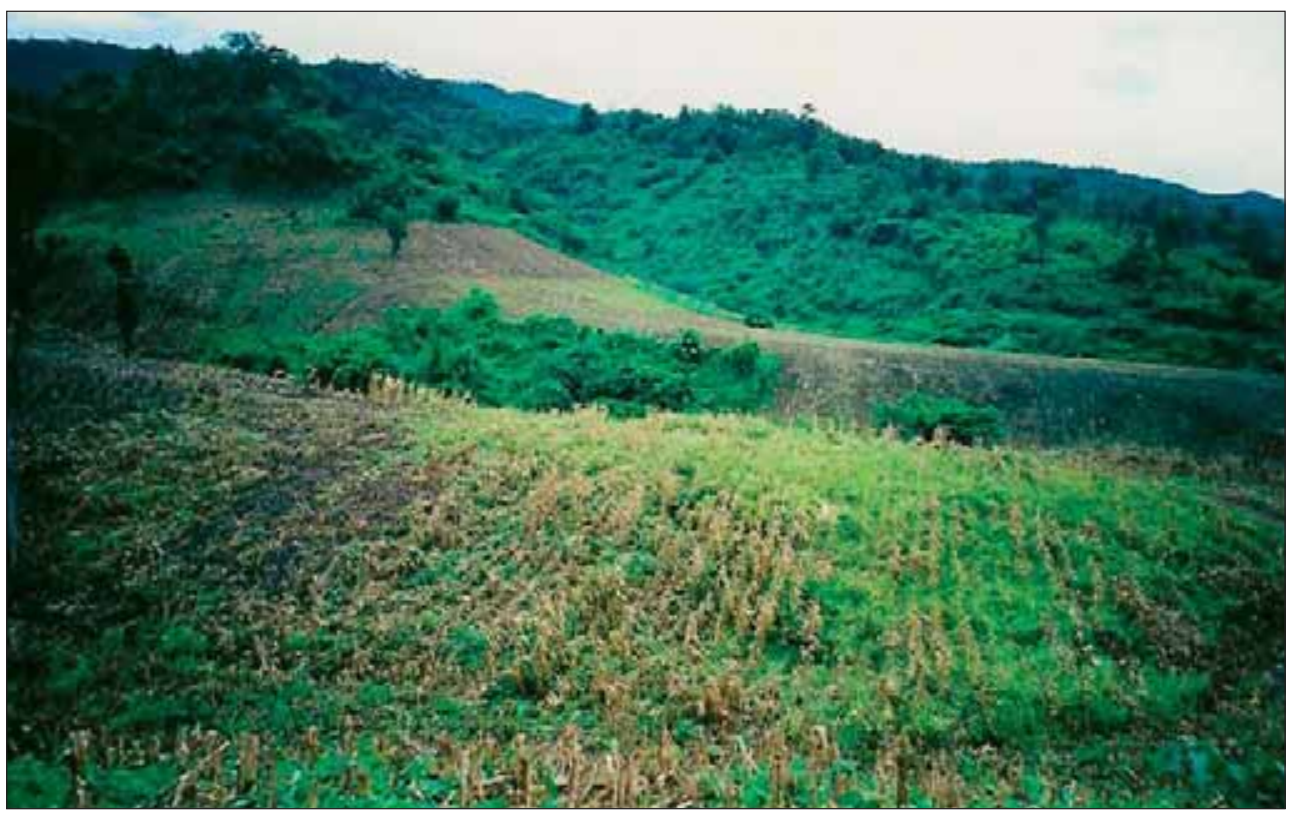

Fig. 10. Low angle fault scarp on surface of Late Quaternary alluvial fan, Thung Chang Segment, Pua Fault.

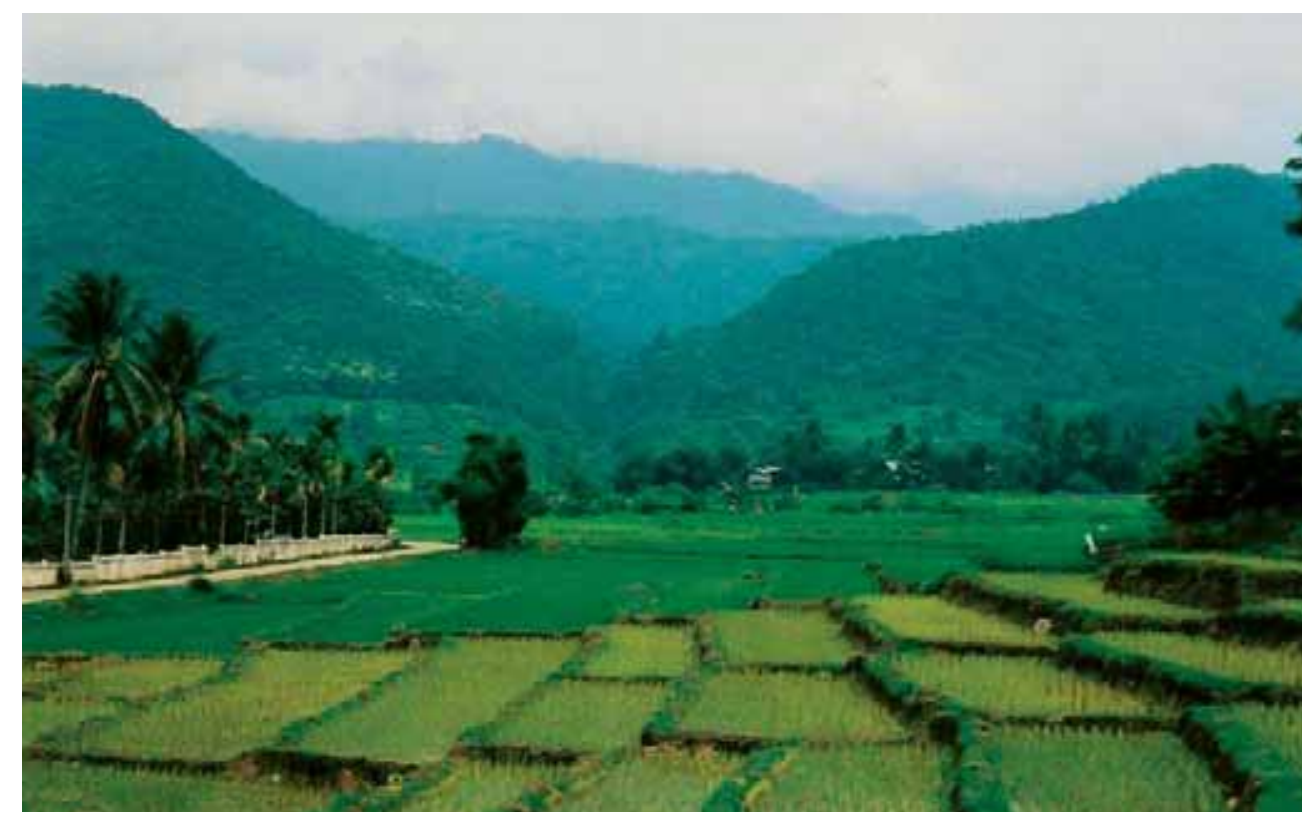

Fig. 11. Wine-glass canyon developed where the Nam Khun crosses the Pua Fault. Compare canyon profile with fig. 8 . 


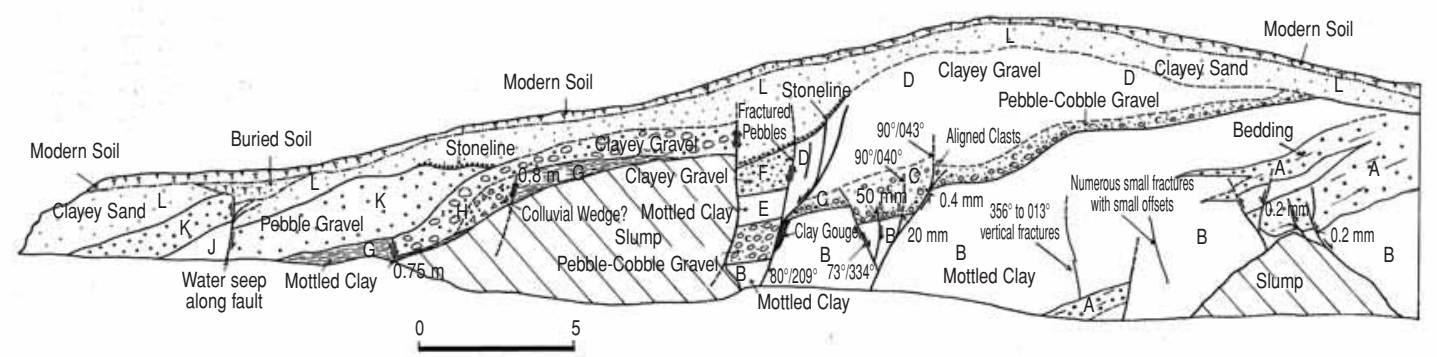

Fig. 12. Log of south-facing exposure of faulted alluvial gravels and lacustrine clays at the southern end of the Pua Fault. Overall sense of displacement is down-to-the-west. Scale in meters.

the base of the escarpment has formed during the Holocene, this $6 \mathrm{~m}$ offset implies a minimum vertical displacement rate of about 0.6 $\mathrm{mm} / \mathrm{yr}$.

Further evidence for Holocene movement on the Santi Suk segment is the exposure of a $30 \mathrm{~m}$ wide fault zone offsetting young soil horizons developed in a sequence of alluvial gravels and lacustrine clays in a gravel pit at Ban Hua Na (fig. 12). The complex nature of faulting exposed in the gravel pit, involving both normal and reverse faulting, along with the mismatch of units across the faults suggest that movement on the Santi Suk Segment involves a significant lateral component. The youngest deposit offset by faulting is a soil horizon developed in clayey gravels, immediately below the modern soil. Offset of this soil is about 0.3 $\mathrm{m}$ down-to-the-east on a west-dipping fault, i.e. reverse movement, and about $0.5 \mathrm{~m}$ down-tothe-west on a west-dipping fault. The offset soil horizon is considered to be Holocene in age on account of its lack of reddening and poorly developed rubification (Woodward-Clyde Federal Services, 1996).

Although this gravel pit exposes faults offsetting very young deposits, there are no stratigraphic markers that can be used to determine the amount or true sense of offset. The westdipping nature of these deposits suggests downto-the-east movement on an east-dipping normal fault, i.e. a fault antithetic to the main Pua Fault. A short east-dipping fault is observed on the opposite side of the basin on aerial photo- graphs, although the geomorphic expression of this fault does not suggest that it has been a particularly active structure.

\section{Mae Chan Fault}

The Mae Chan Fault is an east-west to northeast-southwest striking left-lateral strike-slip fault that extends for about $140 \mathrm{~km}$ from Nam Mae Chan valley in northernmost Thailand near the border with Myanmar, across the Mekong River and into Laos (fig. 3). Hinthong (1995) first recognized deflected drainages, shutter ridges, and sag ponds indicating active strikeslip faulting. Older streams, entrenched in bedrock, are offset by as much as $600 \mathrm{~m}$ (Wood, 2001). Younger streams channeled into Quaternary sediments are offset by a few meters. Preliminary trenching investigations indicate that the most recent movement has been Late Quaternary and possibly Holocene (Rymer et al., 1997).

Some of the best examples of deflected drainages are found near $\mathrm{Ban} \mathrm{Su} \mathrm{Fu}$ at the western part of the fault (fig. 13a-d). Here older, more deeply incised streams are offset by up to 600 $\mathrm{m}$, while younger, shorter streams are offset by 100 to $300 \mathrm{~m}$ (Wood, 2001). As well as deflected drainages, Wood (2001) also mapped a series of offset ridge crests, creating conspicuous shutter ridges and uphill-facing scarps (fig. 14a,b). Using a denudation rate for similar regions of Southeast Asia $(0.1 \mathrm{~mm} / \mathrm{yr})$, Wood 


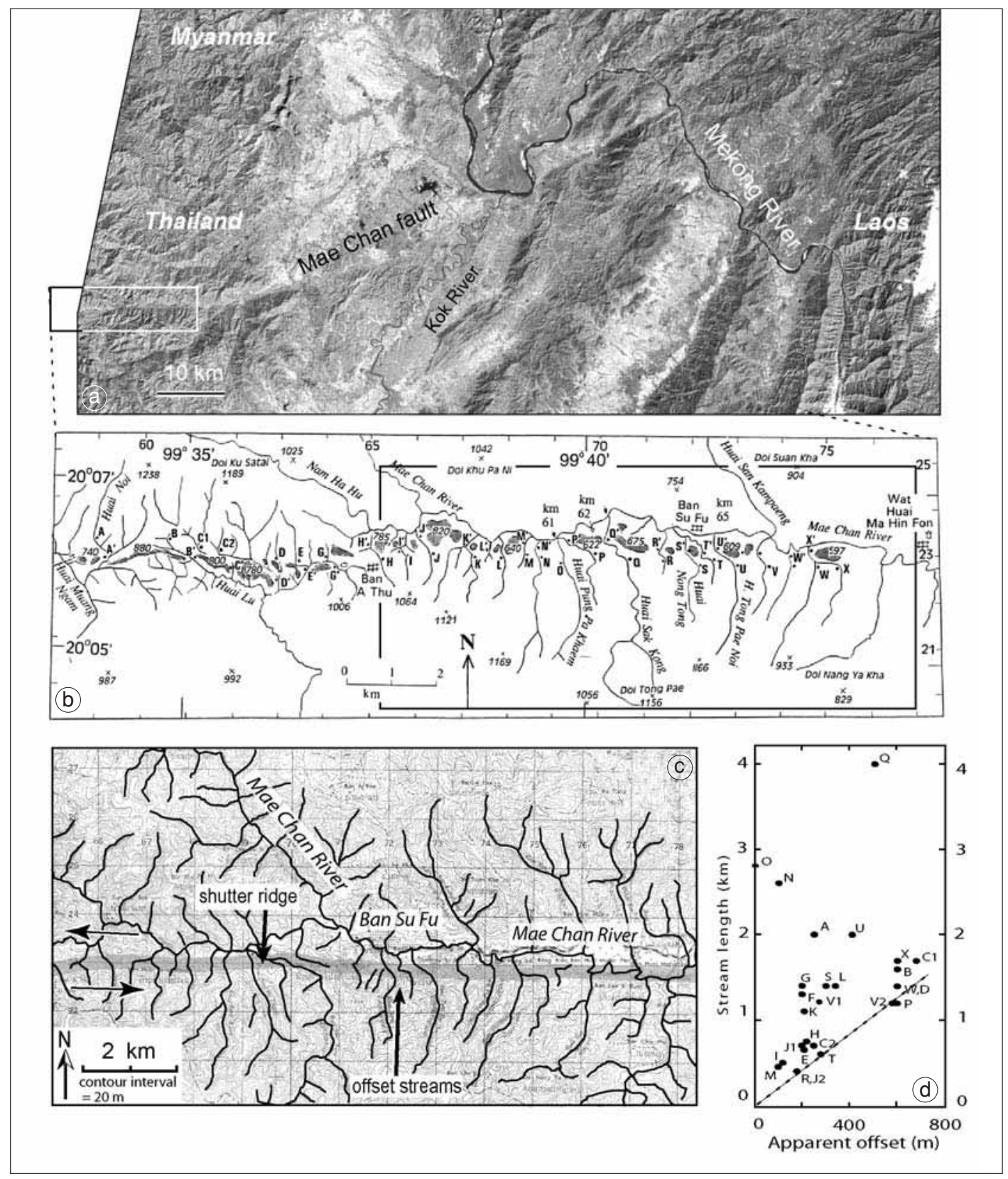

Fig. 13a-d. a) Landsat image of the Mae Chan Fault and Mekong River in northernmost Thailand. River flows from top of image to the southwest (image processed and furnished by Michael J. Rymer, U.S. Geological Survey, Menlo Park, California). b) Offset streams, shutter ridges, and water gaps along the Western Mae Chan Fault. c) Detail of stream offsets near Ban Su Fu. d) Graph of offset versus stream length. One group of streams 0.5 -to-0.7 km long is offset 100 to $300 \mathrm{~m}$, while another group 1.1-to- $1.8 \mathrm{~km}$ long is offset about $600 \mathrm{~m}$. 

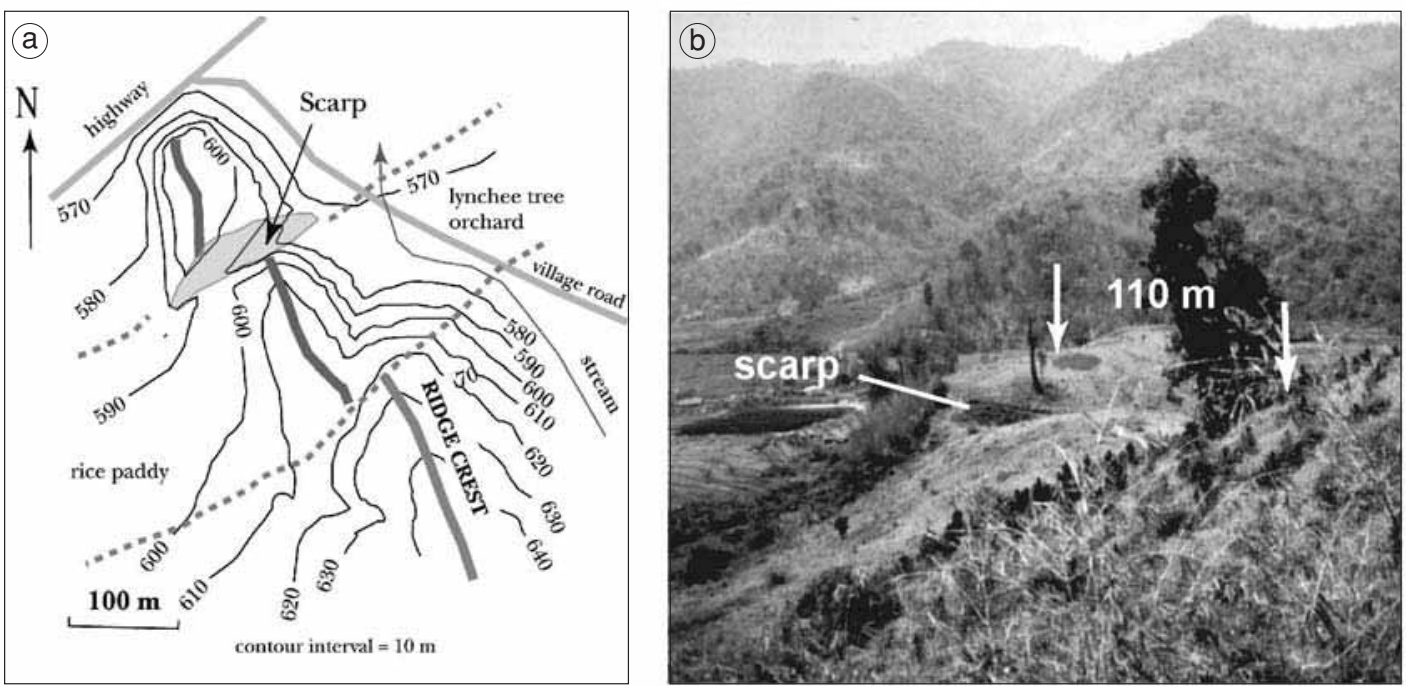

Fig. 14a,b. a) Ridge crest offset creating shutter ridge along the Mae Chan Fault $3 \mathrm{~km}$ west of Ban $\mathrm{Su} \mathrm{Fu}$. b) Looking north along the crest of the offset ridge crest.

(2001) calculated that a time of $200 \mathrm{ka}$ is required to erode a valley extending $1.4 \mathrm{~km}$ into the saprolite-mantled granitic upland south of the fault. This assumes a trapezoid-shaped volume of sediment removed to form the valley $60 \mathrm{~m}$ deep and $500 \mathrm{~m}$ wide at the range front. These streams are typically offset $600 \mathrm{~m}$ (fig. 13d), implying a slip rate of $3 \mathrm{~mm} / \mathrm{yr}$. Because of the many uncertainties in our geomorphicbased estimate of valley age and fault-slip rate, at this point in our studies we believe the slip rate is between 0.3 and $3 \mathrm{~mm} / \mathrm{yr}$.

The Mekong River crosses the Mae Chan Fault (fig. 13a). From the top of the image, the river flows southward to the Golden Triangle in a straight bedrock canyon $600 \mathrm{~m}$ deep that forms the Laos-Myanmar border. Fifteen kilometers north of the mouth of the Kok River the valley floor of the Mekong River broadens to an alluvial plain about $4 \mathrm{~km}$ wide. At the mouth of the Kok River, there is a NE-SW elongate (14 $\mathrm{km}$ by $5 \mathrm{~km}$ ) marshy depression known as Wiang Nong that extends southwest along the north side of the fault (fig. 13a). We interpret this depression as a tectonic pull-apart basin or sag consistent with left-lateral motion of the fault. East of the mouth of the Kok River, the river course deflects east $25 \mathrm{~km}$ (in a left-lateral sense) forming two broad loops north of the fault. The first loop is in an alluvial plain about $8 \mathrm{~km}$ wide, and the second is in a bedrock canyon about $400 \mathrm{~m}$ deep. The offset river then resumes a southerly course in the bedrock canyon and crosses the fault about $10 \mathrm{~km}$ north of Chiang Khong, Thailand (fig. 13a). We agree with Lacassin et al. (1998) that at this crossing the river course appears left-laterally deflected no more than $1.5 \mathrm{~km}$. The fault has clearly affected the course of the Mekong River, but we do not know if the entire $25 \mathrm{~km}$ deflection is a result of tectonic shift. At this point in our studies we do not have a detailed explanation for the abrupt change in the river course at the mouth of the Kok River and the s-loops north of the fault. As the river interacted with the fault it must have continued to flow in the canyons previously incised $300 \mathrm{~m}$ through the northeastsouthwest-trending ranges. If a significant part of the $25 \mathrm{~km}$ deflection is tectonic, it is difficult to explain why the actual fault crossing shows only a $1.5 \mathrm{~km}$ deflection. It is possible that an older course of the Mekong River lies to the 
east on the south side of the fault, but is now covered by a Quaternary-aged basalt field that covers a 15 -square-km area in Laos just south of where the fault crosses the Mekong. A K-Ar age on the basalt is $1.7 \mathrm{Ma}$ (Barr and MacDonald, 1981).

Lacassin et al. (1998) interpret the unusual hairpin loops of the Mekong River crossing the active Nam Ma Fault $60 \mathrm{~km}$ upriver to be the result of Late Cenozoic slip-sense inversion. They suggest that the Nam Ma Fault changed from a right-lateral to a left-lateral slip at some time between 5 and $20 \mathrm{Ma}$. They noted the $1.5 \mathrm{~km}$ shift in the Mekong on the Mae Chan Fault crossing, but did not address the larger deflection of 25 $\mathrm{km}$ noted here. Slip on the order of $25 \mathrm{~km}$ since Late Cenozoic is consistent with the slip rate of $3 \mathrm{~mm} / \mathrm{yr}$ we derived for the small streams near Ban Su Fu. This is corresponds to the upper bound slip rates calculated by Lacassin et al. (1998) from river channel restoration along similar strike-slip faults to the north in Myanmar, Laos, and Yunnan Province, China.

\section{Three Pagodas Fault}

The Three Pagodas Fault Zone (TPFZ) is a $350 \mathrm{~km}$ long, $25 \mathrm{~km}$ wide, northwest-striking zone of distributed faulting extending from just south of Moulmein, Myanmar, across the Three Pagodas Pass, along the Mae Nam Khwae Noi/Mae Nam Khwae Yai (River Kwai) drainage basin, and towards the Gulf of Thailand (fig. 15). At its northern end, the TPFZ either merges with the Sagaing Fault system (fig. 1), or a splay of that fault, in the Andaman Sea at about $16^{\circ} \mathrm{N}$ (fig. 15). Tapponnier et al. (1982) proposed that the TPFZ and the Mae Ping Fault (MPFZ in fig. 1) to the north accommodated the majority of movement along the Malay Peninsula during the early phase (50-20 Ma) of India-Eurasia collision. During this phase of tectonism, movement on these faults was left-lateral, with a total offset of approximately $300 \mathrm{~km}$ (Peltzer and Tapponnier, 1988). Recent thermochronologic studies in Western Thailand have revealed that this phase of left-lateral slip ended about 36 to $33 \mathrm{Ma}$ on the TPFZ (Lacassin et al., 1997). The subsequent change in the plate motion between India and Eurasia causing a reversal in the rotation of Southeast Asia initiated east-west extension across Central and Northern Thailand (Peltzer and Tapponnier, 1988). Coeval with this, movement on the northwest-striking faults on the Malay Peninsula reversed a right-lateral displacement. Right-lateral movement on the TPFZ began about $24 \mathrm{Ma}$ (Lacassin et al., 1997). Earthquake focal mechanisms in the region indicate that right-lateral strike-slip faulting persists to the present day (Le Dain et al., 1984).

Initial investigations of the TPFZ using Landsat imagery concluded that the fault was inactive (EBASCO, 1984). However, Shrestha (1987) identified a number of suspected active fault traces along the Mae Nam Khwae Noi (fig. 16), including one that was claimed to offset an alluvial fan by $1.5 \mathrm{~km}$. Hetrakul et al. (1991) suggested that reservoir-induced seismicity in the area of Khao Laem reservoir may have occurred on a segment of the Three Pagodas Fault. The Yunnan Seismological Bureau (1997) identified three fault splays along the TPFZ that have been active since Middle Pleistocene (240-160 ka) and estimated a slip rate of $0.19 \mathrm{~mm} / \mathrm{yr}$.

Woodward-Clyde Federal Services (1998) carried out reconnaissance investigations of the TPFZ between Three Pagodas Pass and Kanchanaburi (fig. 16). Using aerial photographs and satellite imagery and field reconnaissance, they identified numerous geomorphic features indicative of active faulting, including lateral drainage deflections, scarps on alluvium, shutter ridges, and faceted spurs. Between Three Pagodas Pass and Sangkhlaburi (fig. 16), the fault has a well-defined trace only a few hundred meters wide. South of the international border, the fault zone comprises two parallel strands. The western strand appears to offset a number of small streams in a right-lateral manner. The amount of offset is on the order of several meters to several tens of meters. About $6 \mathrm{~km}$ north of Sangkhlaburi, the eastern fault trace forms a prominent break-inslope and side-hill along the northeastern side of a fault line valley. Streams crossing this fault splay show a minor amount of right-lateral offset. 


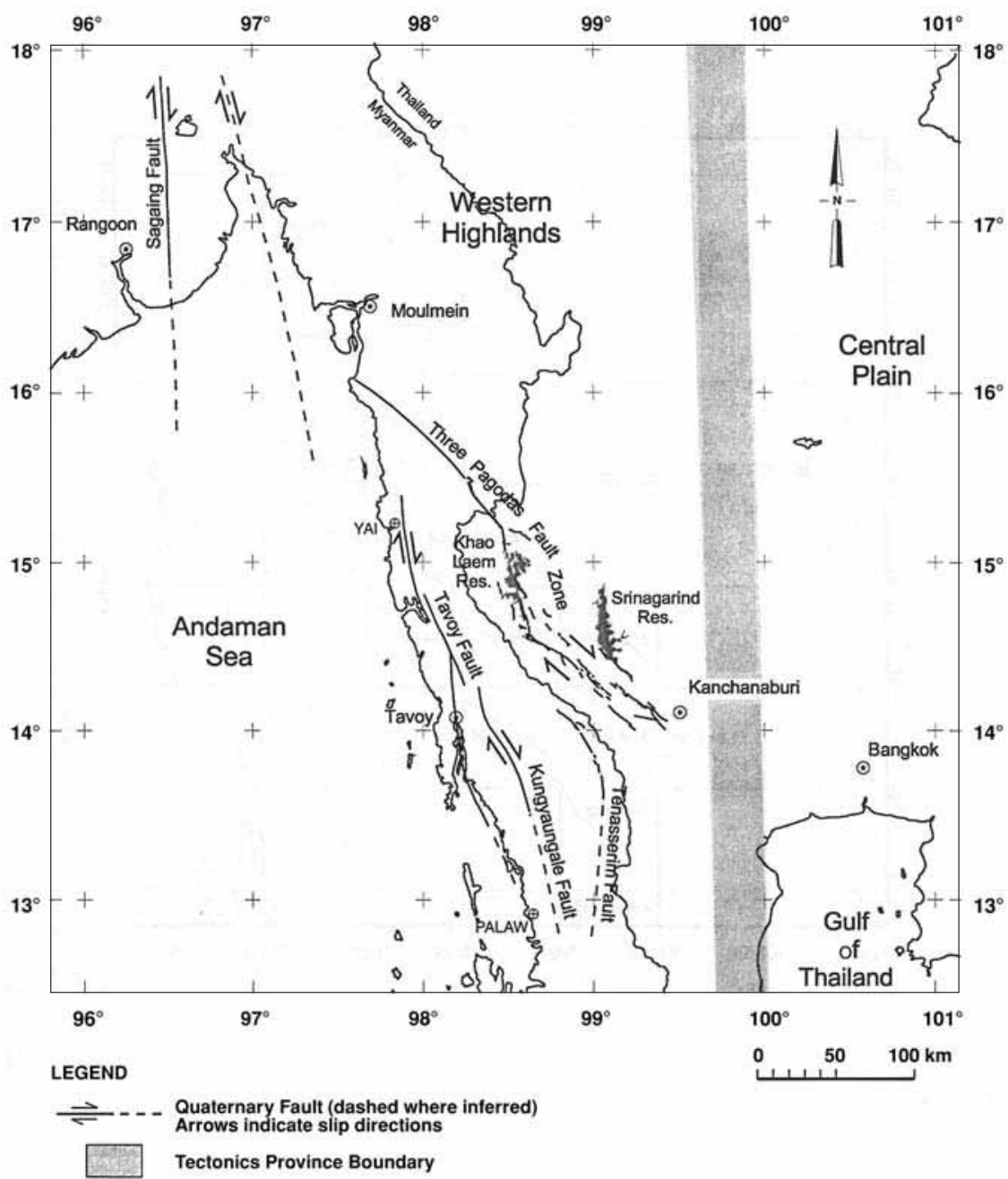

Fig. 15. Active faults in Western Thailand and Myanmar.

At Sangkhlaburi, the strike of the fault changes to a more north-south direction. Immediately north of Khao Laem Reservoir the fault is marked by a prominent west-facing escarpment that steepens towards its base. Aggradation of small alluvial fans at the base of this escarpment and incision of the drainages running out of the escarpment are indicative of a component of vertical down-to-the-west dis- placement. The northern end of this escarpment forms a shutter ridge that deflects drainage in a right-lateral manner.

Further south, below Khao Laem Dam, the easternmost trace of the TPFZ forms a southwest-facing escarpment that bounds a small alluvium-filled basin. This escarpment displays well-developed triangular facets with a stepped or benched profile indicating by Hamblin's 


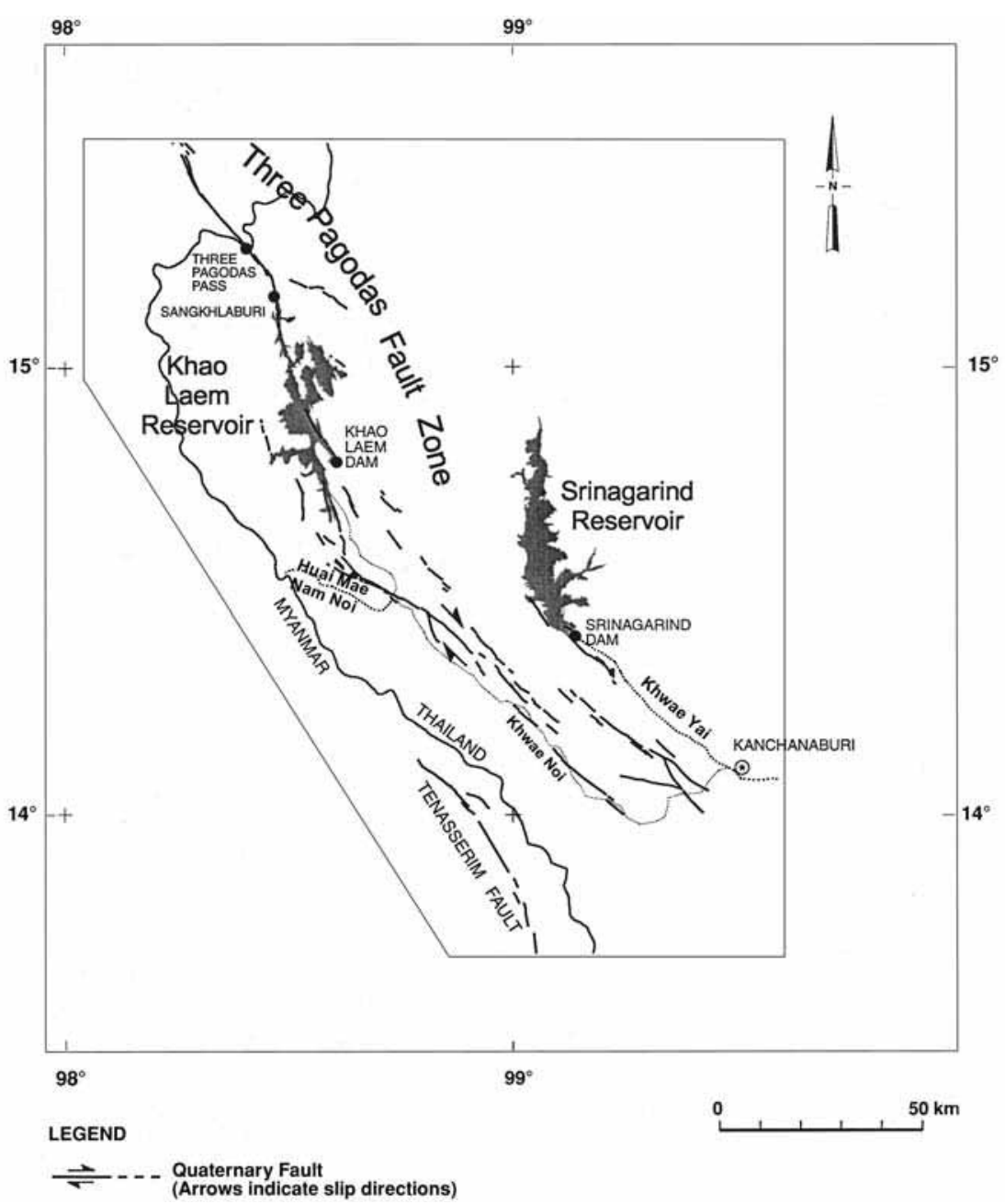

Fig. 16. Simplified map of the Three Pagodas Fault Zone showing localities mentioned in the text.

(1976) criteria that this section of the fault has undergone episodic uplift.

At its confluence with the Huai Mae Nam Noi, the Mae Nam Khwae Noi is deflected in an apparent right-lateral manner (fig. 16). Several reaches of the river downstream also appear to be fault controlled, as are reaches of the Mae Nam Khwae Yai (Woodward-Clyde Federal Services, 1998).
Over most of its length, the TPFZ is expressed in bedrock, or bedrock covered with a thin veneer of Late Holocene alluvium. There are very few exposures of the fault in Late Cenozoic deposits. Along strike from a bedrock scarp, near Rong Rian Yang Thon (fig. 16), Plio-Pleistocene lacustrine and alluvial deposits exposed in a gravel pit are warped and increase in dip from $10^{\circ}$ to $21^{\circ}$ to the west. There is no 
indication of slope movement or any other gravitational instability, therefore this increase in dip, beyond the angle of repose for alluvial sediments, is most likely tectonic in origin.

Based on deflected drainages near Sangkhlaburi, where assumed Late Pleistocene channels are laterally displaced by up to $10 \mathrm{~m}$, the slip rate on the TPFZ is estimated at about $0.1 \mathrm{~mm} / \mathrm{yr}$ (Woodward-Clyde Federal Services, 1998). Across the border in Myanmar, the stronger geomorphic expression of the fault and greater deflection of streams indicates that the slip rate may be as high as $2 \mathrm{~mm} / \mathrm{yr}$ (Woodward-Clyde Federal Services, 1998). This is similar to the level of activity observed on other faults in peninsular Myanmar (Woodward-Clyde Federal Services, 1998).

\section{Discussion}

Recent investigations have identified a number of faults in Northern and Western Thailand that all display evidence for Late Cenozoic movement. These Late Quaternary faults are considered capable of producing large earthquakes.

The Thoen, Pua, Mae Chan, and Three Pagodas fault zones show abundant geomorphic and stratigraphic evidence for Late Quaternary activity. Fault scarps on Quaternary alluvial and colluvial deposits; vertical displacement of Quaternary terrace surfaces; faulting in recent alluvial gravels; well-developed triangular facets along fault escarpments with progressive steepening towards the base of the escarpments; wineglass canyon profiles; and lateral offset of stream courses and ridge crests are all testament to Late Quaternary movement along these faults. Many of these features are also found along the Phrae, Phrae Basin, Nam Pat, Long, and Phayao faults (Fenton et al., 1997).

The predominant displacement on the basinbounding faults of Northern Thailand, with the exception of the Mae Chan Fault, is normal dipslip while in Western Thailand the predominant fault movement is strike-slip. The Pua Fault and the Ban Mai Segment of the Thoen Fault, however, show evidence for lateral displacement. Displacement along the Mae Chan Fault in northernmost Thailand is predominantly left- lateral. We believe that this fault lies within a different seismotectonic province, dominated by strike-slip faulting. With the exception of the Phrae Basin Fault, and small fault splays along the Thoen Fault Zone, recent faulting has been confined to relatively narrow zones along range fronts (Woodward-Clyde Federal Services, 1996). This is similar to the style of faulting that is observed in the Basin and Range Province of the Western United States (dePolo et al., 1991).

The structural complexity and geomorphic heterogeneity of these basin-bounding faults suggests that, like the normal faults in the Basin and Range Province, they are segmented. The Thoen Fault is comprised of four segments (fig. 5). The northern (Ban Mai) segment shows a subordinate left-lateral component of slip while the remainder of the fault shows no apparent lateral offset. The three remaining fault segments are defined on fault geometry (strike and dip of the fault plane) and on the geomorphic expression of the fault (fault scarp heights, scarp angles, etc.); better-defined fault geomorphology indicates a more recently active fault segment. The segmentation of the other faults in Northern Thailand (e.g., the Pua Fault) is also based on similar evidence (Fenton et al., 1997).

Although most seismicity appears diffuse (fig. 3), Bott et al. (1997) consider that only the 1980 earthquake sequence south of Phrae and the 1994 Phan earthquake may be associated with mapped faults; the Phrae and Phayao faults, respectively. The Basin and Range Province in the Western United States shows a similar relationship between mapped faults and contemporary seismicity (e.g., Smith and Arabasz, 1991).

Only three focal mechanisms have been computed to date for earthquakes in Northern Thailand (Bott et al., 1997). These mechanisms are consistent with the geologic data presented in this paper, showing that this region is undergoing east-west to northwest-southeast extension on north- to northeast-striking normal or normal-oblique faults. Focal mechanisms from Western Thailand indicate strike-slip faulting (Le Dain et al., 1984).

The Holocene slip rates for the basin-bounding normal faults in Northern Thailand range between 0.1 and $0.6 \mathrm{~mm} / \mathrm{yr}$ (table I). The Mae 
Chan strike-slip fault may have a slip rate as high as $3 \mathrm{~mm} / \mathrm{yr}$, however this has not been confirmed by paleoseismic trenching (Wood, 2001). Slip rates were calculated from the offset of the youngest geomorphic features or stratigraphic units. Long-term slip rates for these faults, calculated from the cumulative throw across the basin margins (i.e., the sum of sediment thickness within the basin and the height of the range front escarpment along the basin margin), are between 0.02 and 0.07 $\mathrm{mm} / \mathrm{yr}$. The average long-term slip rate is, therefore, about an order of magnitude less than the contemporary slip rate. This suggests that the Late Quaternary has been a period of increased fault activity or renewed activity following a period of quiescence. This is supported by the presence of wineglass canyons and downward-steepening facets along the fault escarpments of prominent range fronts. From these slip rate values and the relatively rare slipper-event data for faults in Northern Thailand, we estimate that the recurrence for large earth- quakes on these faults is of the order of thousands to tens of thousands of years. Slip rates for faults in Western Thailand are less well constrained, but appear to be of the same order of magnitude as those in Northern Thailand (table I). The slip rate for the Three Pagodas Fault is about an order of magnitude less than the recently identified active strike-slip faults across the border in peninsular Myanmar (WoodwardClyde Federal Services, 1998).

Maximum magnitudes estimates for each fault are based on empirical relations between expected rupture dimensions (Wells and Coppersmith, 1994). Maximum magnitude is commonly estimated through a comparison of fault rupture length and magnitude. However, considerable uncertainty often exists in the selection of the appropriate rupture length to be used in the analysis (Schwartz et al., 1984). Rupture lengths of past surface-rupture events on a specific fault may provide direct evidence. No such data exists for Thailand. In the absence of definitive data to the contrary, we conservatively assume that the

Table I. Seismic source parameters of active faults in Northern and Western Thailand.

\begin{tabular}{|c|c|c|c|c|c|c|c|}
\hline Fault & $\begin{array}{l}\text { Length }\left({ }^{1}\right) \\
(\mathrm{km})\end{array}$ & $\begin{array}{l}\text { Age of most recent } \\
\text { movement }\left({ }^{2}\right)\end{array}$ & $\begin{array}{l}\text { Long-term } \\
\text { slip rate }\left(^{3}\right) \\
(\mathrm{mm} / \mathrm{yr})\end{array}$ & $\begin{array}{l}\text { Slip rate } \\
(\mathrm{mm} / \mathrm{yr})\left({ }^{4}\right)\end{array}$ & $\begin{array}{l}\text { Slip-per- } \\
\text { event }\left({ }^{5}\right) \\
(\mathrm{m})\end{array}$ & $\begin{array}{c}\text { Recurrence } \\
\left({ }^{6}\right) \\
(\mathrm{kyr})\end{array}$ & $\begin{array}{c}\text { Maximum } \\
\text { credible } \\
\text { earthquake } \\
\left({ }^{7}\right)(\boldsymbol{M})\end{array}$ \\
\hline Long & 56 & Late Pleistocene & 0.04 & 0.1 & - & - & 7 \\
\hline Nam Pat & 35 & Late Pleistocene & 0.04 & 0.1 & - & - & 7 \\
\hline Phayao & 28 & Late Pleistocene & 0.05 & 0.1 & - & - & 7 \\
\hline Phrae & 51 & Late Pleistocene & 0.07 & 0.1 & - & - & 7 \\
\hline Phrae Basin & 59 & Late Pleistocene & 0.07 & 0.1 & $1.2-1.5$ & $12-15$ & 7 \\
\hline Pua & 68 & Holocene & 0.06 & 0.6 & - & - & $7^{1} / 4$ \\
\hline Thoen & 120 & Holocene & 0.02 & 0.6 & $1.0-1.5$ & $1.7-2.5$ & $71 / 2$ \\
\hline Mae Chan & 140 & Holocene & - & $0.3-3.0$ & - & - & $71 / 2$ \\
\hline Three Pagodas & $350\left(^{8}\right)$ & Holocene? & - & $0.5-2.0$ & - & - & $71 / 2$ \\
\hline
\end{tabular}

(') Fault length exhibiting recent faulting.

${ }^{\left({ }^{2}\right)}$ Relative age estimated from geomorphic relationships and pedologic development.

${ }^{(3)}$ Total vertical displacement across the fault (range height + basin depth) divided by time since basin opening, approximately $33 \mathrm{Ma}$ (Charusiri, 1989). Uncertainties on these slip rate values are at least $\pm 50 \%$.

$\left({ }^{4}\right)$ Total offset of youngest geomorphic feature or stratigraphic unit divided by its relative age. Uncertainties on these values are at least $\pm 50 \%$.

${ }^{(5)}$ Determined from paleoseismic trench excavations

( $\left.{ }^{(}\right)$Estimated by dividing slip-per-event by slip rate.

(7) Estimated moment magnitude from empirical relationships among rupture length, rupture area, and magnitude (Wells and Coppersmith, 1994). Uncertainties in magnitude values are $\pm 1 / 4$.

$\left({ }^{8}\right)$ Total fault length. The complex geometry of this fault suggests that it is very unlikely that the entire fault ruptures in a single event. Maximum magnitude is based on the segmentation model of Woodward-Clyde Federal Services (1998). 
maximum rupture length corresponds to the maximum length of the mapped active fault trace or trace of identified fault segments.

Maximum magnitude estimates also are computed based upon rupture area, which incorporates the maximum rupture length and maximum rupture width. The dip of the fault and thickness of the seismogenic crust are required to estimate down-dip width of the rupture plane. Neither of these properties are well constrained in Northern Thailand. However, because of the similarities between the tectonic setting and crustal properties of Northern Thailand and the Western United States, we use data from the latter to estimate the dip of active faults and the thickness of the seismogenic layer. Doser and Smith (1989) determined that the approximate average dip of normal faults in the interior of the Western United States is about $60^{\circ}$, with a range from about 40 to $90^{\circ}$. For faults in the Northern Basin and Range Province of Northern Thailand, we used a dip of $60^{\circ} \pm 15^{\circ}$ in order to calculate rupture areas.

Moderate-to-large Basin and Range Province earthquakes occur at or near the base of the seismogenic crust, and nearly all of the events have focal depths of $15 \mathrm{~km}$ or less (Doser and Smith, 1989). Many continental areas with youthful mountains appear to be characterized by a seismogenic thickness of $15 \pm 5 \mathrm{~km}$, which corresponds with crustal temperatures less than $350 \pm 100^{\circ} \mathrm{C}$, the upper limit for brittle failure and earthquake generation (Chen and Molnar, 1983). Thus, we assumed $15 \pm 5 \mathrm{~km}$ as the thickness of the seismogenic crust for Northern Thailand (Bott et al., 1997).

The empirical relationships for surface rupture length and rupture area used in this maximum magnitude assessment are those developed by Wells and Coppersmith (1994). The maximum moment magnitude $(\boldsymbol{M})$ for each fault is given in table I.

\section{Conclusions}

Recent geologic studies show Late Quaternary activity along a number of north- to northeast-striking Cenozoic basin-bounding faults in the Northern Basin and Range seismotectonic province in Northern Thailand and along strikeslip faults in the Western Highlands and Mae Chan provinces. Geomorphic indicators of active faulting, including fault scarps on colluvium/alluvium, faceted spurs, wine-glass canyons, linear range fronts, stream knickpoints, and faulted Late Quaternary deposits, are found along six major faults in Northern Thailand. The sense of slip along these faults is predominantly normal dip-slip. The Pua and Thoen faults, however, have minor components of lateral slip. These geomorphic data, and the evidence from limited paleoseismic excavations, show that the most recent surface rupturing events on these faults are either Late Pleistocene or Holocene. From the slip-perevent along the Thoen and Phrae Basin faults, approximately $1.5 \mathrm{~m}$, and the range of slip rates calculated for these faults, we infer that the return period for surface rupturing events on these faults is on the order of 2500 to 15000 years (table I). Empirical relationships between rupture length and earthquake magnitude indicate that these faults are capable of generating earthquakes as large as $\boldsymbol{M} 7$. Thus, like the tectonically-similar Basin and Range extensional province of the Western United States, Northern Thailand is characterized by faults with low slip rates, long recurrence intervals, and large magnitude paleoearthquakes. The Mae Chan Fault in northernmost Thailand and the Three Pagodas Fault Zone in Western Thailand are both marked by scarps on alluvium, deflected drainages, shutter ridges, and sag ponds. Displacement of geomorphic features indicates slip rates between $0.1 \mathrm{~mm} / \mathrm{yr}$ to 3 $\mathrm{mm} / \mathrm{yr}$ for these strike-slip faults. Based on fault segment lengths, both of these faults are capable of generating large, damaging earthquakes of up to $\boldsymbol{M} 7^{1 / 2}$.

\section{Acknowledgements}

This paper arose from several seismic hazards studies carried out for proposed and existing dam sites in Northern and Western Thailand. The financial and management support of the Royal Irrigation Department (RID), the Department of Mineral Resources (DMR), and 
the Electricity Generating Authority of Thailand (EGAT) are gratefully appreciated. Chaiyan Hinthong, Apichard Lumjuan, and Suwit Kosuwan of DMR, and Supawan Klaipongpan of EGAT are thanked for facilitating these investigations and for providing stimulating discussions on the tectonics of Thailand and Southeast Asia. C. Fenton thanks his many colleagues at URS who participated in various aspects of these investigations. S. Wood thanks the faculty of the Department of Geological Sciences of Chiang Mai University for help and hospitality during his sabbatical leave there. The efforts of Ivan Wong and two anonymous reviewers are appreciated for improving on earlier drafts of this paper.

\section{REFERENCES}

Alderson, A., N.A. Holmes and C. Murphy (1994): A summary of the biostratigraphy and biofacies for the Tertiary sequence, Gulf of Thailand, in Proceedings of the International Symposium on Stratigraphic Correlation of Southeast Asia, edited by P. AngsuwathanA, T. WongWanich, W. TANSATHIEN, S. WongSOMSAK and J. TulYaTID, International Geological Correlation Project 306, 292-295

Allen, C.R., A.R. Gillespie, H. Huan, K.E. SieH, Z Buchnan and Z. Chengnan (1984): Red River and associated faults, Yunnan Province, China: Quaternary geology, slip rates, and seismic hazard, Geol. Soc. Am. Bull. 95, 686-700.

BARR, S.M. and A.S. MACDONALD (1981): Geochemistry and geochronology of Late Cenozoic basalts of Southeast Asia, Geol. Soc. Am. Bull., 92, Part II, 1069-1142

Bott, J., I. Wong, S. Prachuab, B. Wechbunthung, C. Hinthong and S. SARAPIROME (1997): Contemporary seismicity in Northern Thailand and its tectonic implications, in Proceedings of the International Conference on Stratigraphy and Tectonic Evolution of Southeast Asia and the South Pacific, edited by P. Dheeradilok, C. Hinthong, P. Chaodumrong, P. Putthapiban, W. Tansathien, C. Utha-aroon, N. SATTYARAK, T. NuchanONG and S. TEChaWAN (Department of Mineral Resources), 453-464.

Charoenprawat, A., S. Chuaviroj, C. Hinthong and C. Chonglakmani (1994): Geological Map of Changwat Lampang Quadrangle Scale 1:250000 (Geological Survey Division, Department of Mineral Resources, Bangkok, Thailand).

Charusiri, P. (1989): Lithophile metallogenic epochs in Thailand: a geological and geochronological investigation, Unpublished Ph.D. Thesis, Queen's University, pp. 819.

CHEN, W. and P. MolnaR (1983): Focal depths of intracontinental and intraplate earthquakes and its implications for the thermal and mechanical properties of the lithosphere, J. Geophys. Res., 88, 4183-4214.
DePolo, C.M. (1994): The maximum background earthquake for the Basin and Range Province, Western North America, Bull. Seismol. Soc. Am., 84, 466-472.

DePolo, C.M., D.G. Clark, D.B. Slemmons and A.R. RAMELLI (1991): Historical surface faulting in the Basin and Range Province, Western North America: implications for fault segmentation, J. Struct. Geol., 13, 123-136.

DosER, D.I. and R.B. SMITH (1989): An assessment of source parameters of earthquakes in the Cordillera of the Western United States, Bull. Seismol. Soc. Am., 79, 1383-1409.

DucrocQ, S., E. Buffetaut, H. Buffetaut-Tong, Y. ChaIMANEE, J.J. JAEGER, R. LACASSIN and V. SUTEETHORN (1992): Tertiary continental basins of Thailand as a result of strike-slip motions induced by the India-Asia collision, J. Southeast Asian Earth Sci., 7, 260.

EBASCO (1984): Evaluation of seismicity in the Kanchanaburi Province, Stage 1 Final Report (unpublished report prepared for Electricity Generating Authority of Thailand).

Fenton, C.H., P. Charusiri, C. Hinthong, A. Lumjuan and B. MANGKONKARN (1997): Late Quaternary faulting in Northern Thailand, in Proceedings of the International Conference on Stratigraphy and Tectonic Evolution of Southeast Asia and the South Pacific, edited by P. Dheeradilok, C. Hinthong, P. Chaodumrong, P. Putthapiban, W. Tansathien, C. Utha-ARoOn, N. SatTyARAK, T. NuchanONG and S. TeChaWAN (Department of Mineral Resources), 436-452.

Fenton, C.H., P. Charusiri and C. Hinthong (1999): Low slip rates versus high erosion rates: recognition and characterization of active faults in a tropical environment, Seismol. Res. Lett., 70, 266.

Hamblin, W.K. (1976): Patterns of displacement along the Wasatch Fault, Geology, 4, 619-622.

Hetrakul, N., B. TanitTiRaporn, R. Sittipod and P. VIVATTANANON (1991): Post evaluation on reservoir triggered seismicity of Khao Laem Dam, in Proceedings Second International Conference on Recent Advances in Geotechnical Earthquake Engineering and Soil Dynamics, edited by S. PraKASH, 1347-1355.

HinTHONG, C. (1995): The study of active faults in Thailand, in Technical Conference on the Progression and Vision of Mineral Resources Development (Department of Mineral Resources), 129-140.

HinthONG, C. (1997): The study of active faults in Thailand, in Report of EANHMP, an Approach to Natural Hazards in Eastern Asia, edited by Y. SHIMAZAKI (Eastern Asia Natural Hazards Mapping Project (EANHMP) and Geological Survey of Japan), 17-22.

HoKe, L. and H.J. CAMPBELL (1995): Active mantle melting beneath Thailand?, in Proceedings of the International Conference on Geology, Geotechnology, and Mineral Resources of Indochina, edited by W. YounGME, C. BuAPHAN, K. SRISUK and R. LERTSIRIVORAKUL (Department of Geotechnology, Khon Kaen University), 13-22.

KIERNAN, K. (1991): Tropical mountain geomorphology and landscape evolution in north-west Thailand, Z. Geomorphol., 35, 187-206.

Klaipongpan, S., V. Chakramanont, J. Pinrode and P. CHITTRAKARN (1991): Geological and seismicity evaluation of Srinagarind Dam, in Proceedings Second International Conference on Recent Advances in Geotechnical Earthquake Engineering and Soil Dynamics, 1357-1363. 
LACASSIN, R., A. RePlumaZ and P.H. Leloup (1998): Hairpin river loops and slip-sense inversion on Southeast Asian strike-slip faults, Geology, 26, 703-706.

Lacassin, R., H. Maluski, P.H. Leloup, P. Tapponnier, C. Hinthong, K. Siribhakdi, S. Chuaviroj and A. CharoenRaVAT (1997): Tertiary diachronic extrusion and deformation of Western Indochina: Structural and ${ }^{40} \mathrm{Ar} /{ }^{39} \mathrm{Ar}$ evidence from NW Thailand, J. Geophys. Res., 102, 10,013-10,037.

Le Dain, A.Y., P. TAPPONiER and P. Molnar (1984): Active faulting and tectonics of Burma and surrounding regions, J. Geophys. Res., 89, 453-472.

LORENZETTI, E.A., P.A. BRENNAN and S.C. HoOK (1994): Structural styles in rift basins: interpretation methodology and examples from Southeast Asia, Bull. Am. Assoc. Pet. Geol., 78, 1,152.

MacDonald, A.S., S.M. BARR, G.R. DunNing and W. YAOWANOIYOTHIN (1993): The Doi Inthanon metamorphic core complex in NW Thailand: age and tectonic significance, J. Southeast Asian Earth Sci., 8 (1-4), 117-125.

Malod, J.A. and B.M. Kemal (1996): The Sumatra margin: oblique subduction and lateral displacement of the accretionary prism, in Tectonic Evolution of Southeast Asia, edited by R. Hall and D.J. Blundell, Geol. Soc. Spec. Publ., 106, 19-28.

McCabe, R., M. Celaya, J. Cole, H.-C. Han, T. Ohnstad, V. PAIJITPRAPAPON and V. THITIPAWARN (1988): Extension tectonics: the Neogene opening of the north-south trending basins of Central Thailand, J. Geophys. Res., 93, 11,899-11,910.

McCabe, R., S. Harder, J.T. Cole and E. Lumadyo (1993): The use of paleomagnetic studies in understanding the complex Tertiary tectonic history of east and southeast Asia, J. Southeast Asian Earth Sci., 8 (1-4), 257-268.

MCCAFFREY, R. (1996): Slip partitioning at convergent plate boundaries of SE Asia, in Tectonic Evolution of Southeast Asia, edited by R. Hall and D.J. Blundell, Geol. Soc. Spec. Publ., 106, 3-18

McCalpin, J.P. (1996): Paleoseismology (Academic Press), pp. 588.

Molnar, P. and Q. Deng (1984): Faulting associated with large earthquakes and the average rate of deformation in Central and Eastern Asia, J. Geophys. Res., 89, 6,2036,227 .

Nutalaya, P. (1994): Assessment and mitigation of earthquakes: selected areas of Southeast Asia, in Reduction in Asia and the Pacific, vol. II: Seismic and Volcanic Hazards, Disaster Mitigation and Monitoring Systems (United Nations Economic and Social Commission for Asia and the Pacific), 205-260

NutAlayA, P., S. SodSRI and E.P. ARnOLd (1985): Thailand, Series on Seismology, (Southeast Asia Association of Seismology and Earthquake Engineering), vol. II, pp. 403.

O'LEARY, J. and G.S. HiLl (1989): Tertiary basin development in the Southern Central Plains, Thailand, in Proceedings of the International Symposium on Intermontaine Basins: Geology and Resources, edited by T. THANASUTHIPITAK and P. OUNCHANUM (Chiang Mai University), 254-264.

Olinstad, T, T. Moriarty, S. Harder and R. MCCABE (1989): Cenozoic rifting in Thailand, Eos, Trans. Am. Geophys. Un., 70 (suppl.), 1343.

PACKHAM, G.H. (1993): Plate tectonics and the development of sedimentary basins of the dextral regime in Western Southeast Asia, J. Southeast Asian Earth Sci., 8 (1-4), 497-511.

Peltzer, G. and P. TAPPONNIER (1988): Formation and evolution of strike-slip faults, rifts, and basins during the IndiaAsia collision: an experimental approach, J. Geophys. Res., 93, 15,085-15,117.

Perez, R.R., B.P. Rhodes, J.R. Liles, A. Lumjuan and S. Kosuwan (1999): The Mae Kuang Fault: an active strikeslip fault in Northern Thailand, Abstracts with Program, Geol. Soc. Am., 31, A-428.

PiYAsin, S. (1974): Geological Map of Thailand, Changwat Uttaradit Scale 1:250 000 (Geological Survey Division, Department of Mineral Resources, Bangkok, Thailand).

Polachan, S., S. Pradidtan, C. Tongtaow, S. Janmaha, K. INTRAWIJTR and C. SANGSUWAN (1991): Development of Cenozoic basins in Thailand, Mar. Pet. Geol., 8, 84-97.

RAKSASKulWONG, M. and A. ThiENPRASERT (1991): Heat flow studies and geothermal energy development in Thailand, J. Thai Geosci., 2, 111-123.

RatanasthiEn, B. (1986): The effect of Pleistocene volcanic activity to Mae Moh coal-bearing formation, in Proceedings of the Workshop on Economic Geology, Tectonics, Sedimentary Processes and Environment of the Quaternary of Southeast Asia, edited by N. THIRAMONGKOL (International Geological Correlation Program), 45-52.

REMus, D., M. WEBSTER and K. KEAWKAN (1993): Rift architecture and sedimentology of the Phetchabun intermontaine basin, Central Thailand, J. Southeast Asian Earth Sci., 8 (1-4), 421-432.

Rhodes, B. P., J.A. Blum and T.R. Devine (1996): Tectonic implication of Miocene (?) stretching in the Western Ranges metamorphic core complex, Northern Thailand, 28, Geol. Soc. Am., Abstracts with Programs, A-371.

Richter, B., M. Fuller, E. SchmidtKe, U.T. Myint, U.T. Ngwe, U.M. Win and S. Bunopas (1993): Paleomagnetic results from Thailand and Myanmar: implications for the interpretation of tectonic rotations in southeast Asia, J. Southeast Asian Earth Sci., 8 (1-4), 247-255.

Rymer, M.J., R.J. Weldon II, C.S. Prentice, S. Kosuwan, A. LumJuAn and N. Muangnoicharoen (1997): Tectonic setting and Late Quaternary activity along the Mae Chan Fault, Northern Thailand and Western Laos, Geol. Soc. Am., Abstracts with Programs, 29, 229-230.

SCHWARTZ, D.P. K.J. COPPERSMITH and F.H. SwAN III (1984): Methods for estimating maximum earthquake magnitudes, in Proceedings of the Eighth World Conference on Earthquake Engineering (Prentice-Hall), 279-285.

Shrestha, P.M. (1987): Investigation of active faults in Kanchanaburi Province, Thailand: Bangkok, Asian Institute of Technology, Unpublished M.Sc. Thesis, pp. 106.

SIRIBHAKDI, K. (1986): Seismogenic of Thailand and periphery, in 1st Workshop on Earthquake Engineering and Hazard Mitigation, edited by P. LUKKUNAPRASIT, K. Chandrangsu, S. Poobrasert and M. MahasuveraCHAI (Southeast Asia Association of Seismology and Earthquake Engineering (SEASEE) and National Earthquake Committee of Thailand), 151-158.

Smith, R.B. and W.J. Arabasz (1991): Seismicity of the Intermountain Seismic Belt, in Neotectonics of North 
America, edited by D.B. SLemmons, E.R. Engdahl, M.D. ZoBACK and D.D. BLACKWELL (Geological Society of America Decade Map), vol. 1, 185-228.

Sutthirat, C., P. Charusiri, W. Pongsapitch, E. Farrar and R. LANDGRIDGe (1995): A Late Pliocene Ko Kha Sop Prap and Nam Cho basaltic eruption, Northern Thailand: evidences from geology and ${ }^{40} \mathrm{Ar} /{ }^{39} \mathrm{Ar}$ geochronology, in Proceedings of the International Conference on Geology, Geotechnology, and Mineral Resources of Indochina, edited by W. Youngme, C. BuAPHAN, K. SRISUK and R. LERTSIRIVORAKUL (Department of Geotechnology, Khon Kaen University), 247-253.

TAPPONNIER, P, G. PeltZer, L.Y. LeDAin, R. ARMUO and P. CoBBold (1982): Propagating extrusion tectonics in Asia: new insights from simple experiments with plasticine, Geology, 10, 611-616.

ThIRAMONGKOL, N. (1986): Neotectonism and rate of uplift in the eastern margin of the lower central plain of Thailand, in Proceedings of the Workshop on Economic Geology, Tectonics, Sedimentary Processes and Environment of the Quaternary of Southeast Asia, edited by N. THIRAMONGKOL (International Geological Correlation Program), 35-44.

Vella, P. (1983): Tensional faults in Tertiary strata, Mae Moh, Thailand, J. Geol. Soc. Thailand, 6, 13-15.

Wells, D.L. and K.J. CopPersmith (1994): New empirical relationships among magnitude, rupture length, rupture width, rupture area, and surface displacement, Bull. Seismol. Soc. Am., 84, 974-1002.
Wong, I.G., C.H. Fenton, J.D.J. Bott, A.M. Becker, R.K. Green, C. Hinthong and S. SARAPIROME (1997): Seismic hazards in Northern Thailand, Seismol. Res. Lett., $68,316$.

Wood, S.H. (1995): Late Cenozoic faulting in mountainous regions of low but persistant historic seismicity: Hells Canyon (NW U.S.A.) and Northern Thailand and the meaning of «active fault», in IUGG XXI General Assembly, Abstracts Week B, B344.

Wood, S.H. (2001): Slip-rate estimate from offset streams, valley volumes, and denudation rate: Mae Chan Fault, Northern Thailand, Eos, Trans. Am. Geophys. Un., 82, 932.

Woodward-Clyde Federal Services (1996): Seismic hazards evaluation, environmental impact assessment: geological aspect, Kaeng Sua Ten Dam Project, Changwat Phrae, Unpublished Report prepared by GMT Consultants and Others for Department of Mineral Resources, 4 vols. (English and Thai).

Woodward-Clyde Federal Services (1998): Preliminary seismic hazard evaluation of Khao Laem and Srinigarind dams, Thailand, Unpublished Report prepared for Electricity Generating Authority of Thailand, Bangkruay, Nontaburi 11000.

Yunnan Seismological Bureau (1997): Report on Three Pagoda Fault Zone from downstream of Khao Laem dam to Sai Yok waterfall: Seismological Bureau of Yunnan Province, China, Unpublished Report prepared for Electricity Generating Authority of Thailand, pp. 29. 
